Supporting Information

\title{
Synthetic Anion Transporters as Endoplasmic Reticulum (ER) Stress Inducers
}

Adil S. Aslam, ${ }^{a}$ Ahmed Fuwad, ${ }^{d}$ Hyunil Ryu, ${ }^{b}$ Baskar Selvaraja, ${ }^{c}$ Jae-Won Song, ${ }^{a}$ Dae Won Kim, ${ }^{e}$ Sun Min Kim, ${ }^{d}$ Jae Wook Lee, ${ }^{*}, \mathrm{c}$ Tae-Joon Jeon, ${ }^{*}, \mathrm{~b}$ and DongGyu Cho*, a

\author{
dgcho@inha.ac.kr
}

${ }^{a}$ Department of Chemistry and Chemical Engineering, Inha University, Incheon, 22212, Republic of Korea

${ }^{b}$ Department of Biological Engineering, Inha University, Incheon, 22212, Republic of Korea

${ }^{c}$ Natural Product Research Center, Korea Institute of Science and Technology, Gangneung Institute, Gangneung, 25451,

Republic of Korea

${ }^{d}$ Department of Mechanical Engineering, Inha University, Incheon, 22212, Republic of Korea

eDepartment of Biochemistry, College of Dentistry, Gangneung Wonju National University, Gangnueng, 25457, Republic of Korea

\section{Contents}

General experimental and synthetic details

S2

Spectroscopic titrations

S4

DFT calculations

$\mathrm{Tl}^{+} / \mathrm{ANTS}$ assay

Chloride efflux studies

Patch clamp experiments

Biological Data 


\section{General and Synthetic details}

Reagents were purchased at the highest commercial quality and used without further purification, unless otherwise stated. Yields of synthesized compounds were measured after chromatographic purification. ${ }^{1} \mathrm{H},{ }^{19} \mathrm{~F}$, and ${ }^{13} \mathrm{C}-\mathrm{NMR}$ spectra were measured at $25{ }^{\circ} \mathrm{C}$ using $400-\mathrm{MHz}$ spectrometers. HRMS were recorded by EI methods using a magnetic sector-electric sector double focusing analyzer.

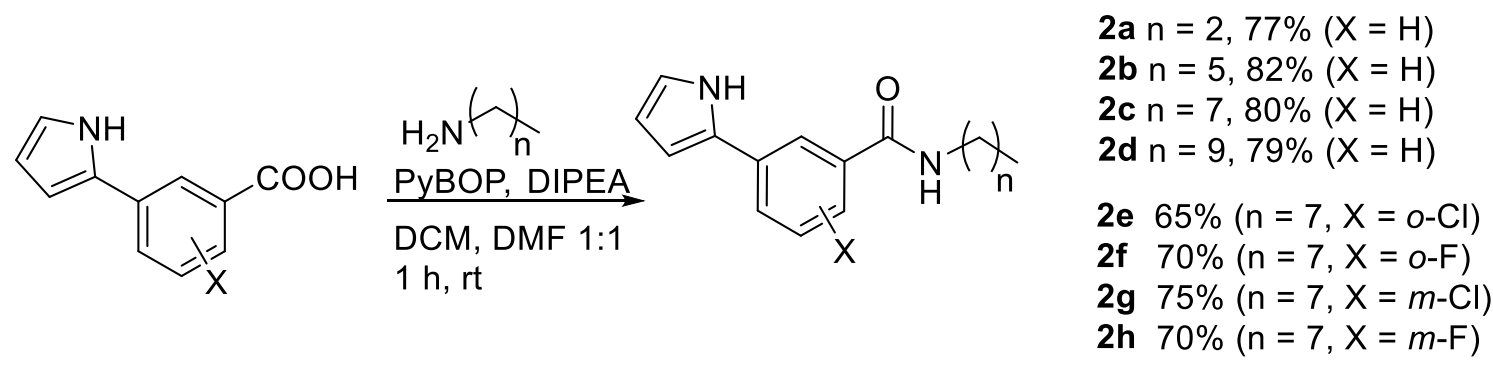

Scheme S1 Synthetic scheme of $\mathbf{2 a - 2 h}$

\section{General procedure of $2 \mathrm{a}-2 \mathrm{~h}$}

\section{N-propyl-3-(1H-pyrrol-2-yl)benzamide (2a)}

DIPEA (44.5 $\mu \mathrm{L}, 0.255 \mathrm{mmol})$ and PyBop $(221.5 \mathrm{mg}, 0.426 \mathrm{mmol})$ were added to a stirred solution of carboxylic acid $(40 \mathrm{mg}, 0.213 \mathrm{mmol})$ in anhydrous solvents $\left(1 \mathrm{~mL}\right.$ of DMF and $1 \mathrm{~mL}$ of $\left.\mathrm{CH}_{2} \mathrm{Cl}_{2}\right)$ under $\mathrm{N}_{2}$. After $30 \mathrm{~min}$, amine $(70 \mu \mathrm{L}, 0.85 \mathrm{mmol})$ was added dropwise to the reaction mixture under $\mathrm{N}_{2}$. The solution was stirred for $1 \mathrm{~h}$. The solvent was evaporated under reduced pressure, and the residue was diluted with ethyl acetate and washed with water. The organic phases were dried with $\mathrm{Na}_{2} \mathrm{SO}_{4}$ and then concentrated under reduced pressure. The resulting residue was purified by a silica gel column (Ethyl Acetate:Hexane $=2: 3$ ) to afford the compound $(37 \mathrm{mg}, 77 \%) .{ }^{1} \mathrm{H}$ NMR $(400 \mathrm{MHz}$, Chloroform- $d$ ) $\delta 8.62$ (bs, 1H), $7.91(\mathrm{dd}, 1.5,1.5 \mathrm{~Hz}, 1 \mathrm{H}), 7.60(\mathrm{ddd}, J=7.7,1.5,1.5 \mathrm{~Hz}, 1 \mathrm{H}), 7.48$ (ddd, $J=7.6,1.5,1.5 \mathrm{~Hz}$, $1 \mathrm{H}), 7.39(\mathrm{dd}, J=7.7,7.7 \mathrm{~Hz}, 1 \mathrm{H}), 6.88(\mathrm{~m}, 1 \mathrm{H}), 6.57(\mathrm{~m}, 1 \mathrm{H}), 6.30(\mathrm{~m}, 1 \mathrm{H}), 6.15(\mathrm{~s}, 1 \mathrm{H}), 3.43(\mathrm{~m}, 2 \mathrm{H})$, $1.65(\mathrm{tq}, J=7.5,7.5 \mathrm{~Hz}, 2 \mathrm{H}), 0.99(\mathrm{t}, J=7.5 \mathrm{~Hz}, 3 \mathrm{H}) ;{ }^{13} \mathrm{C}$ NMR $(101 \mathrm{MHz}$, Chloroform- $d$ ) $\delta 167.82$, 135.39, 133.48, 131.24, 129.09, 126.90, 123.83, 122.44, 119.61, 110.24, 106.70, 41.95, 22.99, 11.52; HRMS-EI: $\mathrm{m} / \mathrm{z}$ [M] ${ }^{+}$calcd for $\mathrm{C}_{14} \mathrm{H}_{16} \mathrm{~N}_{2} \mathrm{O}_{2}: 228.1263$; found: 228.1265 .

\section{N-hexyl-3-(1H-pyrrol-2-yl)benzamide (2b)}

The titled compound was obtained by following the above general procedure of $2 \mathbf{2 a}(59 \mathrm{mg}, 82 \%) .{ }^{1} \mathrm{H}$ NMR (400 MHz, Chloroform-d) $\delta 8.59$ (bs, 1H), 7.90 (dd, J = 1.5, $1.5 \mathrm{~Hz}, 1 \mathrm{H}), 7.60$ (ddd, J = 7.8, 1.5, $1.5 \mathrm{~Hz}, 1 \mathrm{H}), 7.48(\mathrm{ddd}, \mathrm{J}=7.8,1.5,1.5 \mathrm{~Hz}, 1 \mathrm{H}), 7.39(\mathrm{dd}, \mathrm{J}=7.7,7.7 \mathrm{~Hz}, 1 \mathrm{H}), 6.88(\mathrm{~m}, 1 \mathrm{H}), 6.58(\mathrm{~m}$, $1 \mathrm{H}), 6.30(\mathrm{~m}, 1 \mathrm{H}), 6.11(\mathrm{bs}, 1 \mathrm{H}), 3.46(\mathrm{td}, \mathrm{J}=7.2,5.7 \mathrm{~Hz}, 2 \mathrm{H}), 1.61(\mathrm{tt}, J=7.2,7.2 \mathrm{~Hz}, 3 \mathrm{H}), 1.46-1.11$ $(\mathrm{m}, 6 \mathrm{H}), 0.89(\mathrm{~d}, \mathrm{~J}=6.9 \mathrm{~Hz}, 3 \mathrm{H}) ;{ }^{13} \mathrm{C}$ NMR $(101 \mathrm{MHz}$, Chloroform- $d) \delta 167.75,135.41,133.47,131.24$, $129.08,126.88,123.83,122.44,119.60,110.24,106.70,40.32,31.58,29.70,26.75,22.64,14.10$; HRMS-EI: m/z [M] $]^{+}$calcd for $\mathrm{C}_{17} \mathrm{H}_{22} \mathrm{~N}_{2} \mathrm{O}: 270.1732$; found: 270.1733

\section{N-octyl-3-(1H-pyrrol-2-yl)benzamide (2c)}

The titled compound was obtained by following the above general procedure of $2 \mathbf{2 a}(38 \mathrm{mg}, 80 \%) .{ }^{1} \mathrm{H}$ NMR (400 MHz, Chloroform-d) $\delta 8.61(\mathrm{bs}, 1 \mathrm{H}), 7.90(\mathrm{dd}, \mathrm{J}=1.5,1.5 \mathrm{~Hz}, 1 \mathrm{H}), 7.60(\mathrm{~m}, 1 \mathrm{H}), 7.48(\mathrm{~d}, \mathrm{~J}$ $=7.9 \mathrm{~Hz}, 1 \mathrm{H}), 7.39(\mathrm{dd}, \mathrm{J}=7.7,7.7 \mathrm{~Hz}, 1 \mathrm{H}), 6.88(\mathrm{~m}, 1 \mathrm{H}), 6.57(\mathrm{~m}, 1 \mathrm{H}), 6.30(\mathrm{~m}, 1 \mathrm{H}), 6.11(\mathrm{bs}, 1 \mathrm{H})$, $3.45(\mathrm{td}, \mathrm{J}=7.2,5.8 \mathrm{~Hz}, 2 \mathrm{H}), 1.61(\mathrm{tt}, J=7.2,7.2 \mathrm{~Hz}, 2 \mathrm{H}), 1.32(\mathrm{~m}, 10 \mathrm{H}), 0.87(\mathrm{t}, \mathrm{J}=6.9 \mathrm{~Hz}, 3 \mathrm{H}) ;{ }^{13} \mathrm{C}$ NMR (101 MHz, Chloroform-d) $\delta$ 167.74, 135.39, 133.45, 131.23, 129.09, 126.88, 123.82, 122.45, 119.61, 110.26, 106.71, 40.33, 31.89, 29.74, 29.39, 29.30, 27.11, 22.74, 14.19; HRMS-EI: m/z [M] ${ }^{+}$ calcd for $\mathrm{C}_{19} \mathrm{H}_{26} \mathrm{~N}_{2} \mathrm{O}: 298.2045$; found: 298.2047 


\section{N-decyl-3-(1H-pyrrol-2-yl)benzamide (2d)}

The titled compound was obtained by following the above general procedure of $2 \mathbf{a}(41 \mathrm{mg}, 79 \%) .{ }^{1} \mathrm{H}$ NMR (400 MHz, Chloroform-d) $\delta 8.59(\mathrm{bs}, 1 \mathrm{H}), 7.90(\mathrm{~s}, 1 \mathrm{H}), 7.59(\mathrm{~m}, 1 \mathrm{H}), 7.47(\mathrm{~m}, 1 \mathrm{H}), 7.39(\mathrm{dd}, J=$ 7.7, $7.7 \mathrm{~Hz}, 1 \mathrm{H}), 6.88(\mathrm{~m}, 1 \mathrm{H}), 6.58(\mathrm{~s}, 1 \mathrm{H}), 6.30(\mathrm{~m}, 1 \mathrm{H}), 6.11(\mathrm{bs}, 1 \mathrm{H}), 3.45(\mathrm{td}, J=7.3,5.8 \mathrm{~Hz}, 2 \mathrm{H})$, $1.61(\mathrm{tt}, J=7.3,7.3 \mathrm{~Hz}, 2 \mathrm{H}), 1.45-1.16(\mathrm{~m}, 14 \mathrm{H}), 0.87(\mathrm{t}, 6.5 \mathrm{~Hz}, 3 \mathrm{H}) ;{ }^{13} \mathrm{C} \mathrm{NMR}(101 \mathrm{MHz}$, Chloroform- $d$ ) $\delta 167.76,135.42,133.47,131.23,129.09,126.88,123.83,122.47,119.60,110.26,106.72$, 40.33, 31.97, 29.75, 29.64, 29.42, 29.39, 27.10, 22.76, 14.19 (one $\mathrm{sp}^{3}$ carbon may be overlapped); HRMS-EI: $\mathrm{m} / \mathrm{z}[\mathrm{M}]^{+}$calcd for $\mathrm{C}_{21} \mathrm{H}_{30} \mathrm{~N}_{2} \mathrm{O}: 326.2358$; found: 326.2359

\section{2-chloro-N-octyl-5-(1H-pyrrol-2-yl)benzamide (2e)}

The titled compound was obtained by following the above general procedure of $2 \mathbf{a}(126 \mathrm{mg}, 65 \%) .{ }^{1} \mathrm{H}$ NMR (400 MHz, Chloroform- $d$ ) $\delta 8.59(\mathrm{~s}, 1 \mathrm{H}), 7.77(\mathrm{~d}, J=2.3 \mathrm{~Hz}, 1 \mathrm{H}), 7.45(\mathrm{dd}, J=8.3,2.3 \mathrm{~Hz}, 1 \mathrm{H})$, $7.35(\mathrm{~d}, J=8.4 \mathrm{~Hz}, 1 \mathrm{H}), 6.88(\mathrm{td}, J=2.8,1.4 \mathrm{~Hz}, 1 \mathrm{H}), 6.53(\mathrm{~m}, 1 \mathrm{H}), 6.28(\mathrm{~m}, 2 \mathrm{H}), 3.47(\mathrm{td}, J=7.2,5.8$ $\mathrm{Hz}, 2 \mathrm{H}), 1.63(\mathrm{tt}, J=7.2,7.2 \mathrm{~Hz}, 2 \mathrm{H}), 1.48-1.21(\mathrm{~m}, 10 \mathrm{H}), 0.88(\mathrm{t}, J=7.2,6.7 \mathrm{~Hz}, 3 \mathrm{H}) ;{ }^{13} \mathrm{C}$ NMR $(101$ MHz, Chloroform- $d$ ) $\delta 166.55,135.31,132.19,130.68,130.17,127.40,126.67,125.15,120.00,110.36$, $107.11,40.40,31.87,29.49,29.32,29.28,27.07,22.72,14.17 ;$ HRMS-EI: $\mathrm{m} / \mathrm{z}[\mathrm{M}]^{+}$calcd for $\mathrm{C}_{19} \mathrm{H}_{25} \mathrm{ClN} 2 \mathrm{O}: 332.1655$; found: 332.1656

\section{2-fluoro-N-octyl-5-(1H-pyrrol-2-yl)benzamide (2f)}

The titled compound was obtained by following the above general procedure of $\mathbf{2 a}(108 \mathrm{mg}, 70 \%) .{ }^{1} \mathrm{H}$ NMR (400 MHz, Chloroform- $d$ ) $\delta 8.59(\mathrm{~s}, 1 \mathrm{H}), 8.15(\mathrm{dd}, J=7.2,2.6 \mathrm{~Hz}, 1 \mathrm{H}), 7.57$ (ddd, $J=8.7,4.7$, $2.6 \mathrm{~Hz}, 1 \mathrm{H}), 7.10(\mathrm{dd}, J=11.7,8.7 \mathrm{~Hz}, 1 \mathrm{H}), 6.87(\mathrm{~m}, 1 \mathrm{H}), 6.52(\mathrm{~m}, 1 \mathrm{H}), 6.28(\mathrm{~m}, 1 \mathrm{H}), 3.48(\mathrm{tdd}, J=7.1$, $5.5,1.5 \mathrm{~Hz}, 2 \mathrm{H}), 1.67(\mathrm{~m}, 2 \mathrm{H}), 1.45-1.15(\mathrm{~m}, 10 \mathrm{H}), 0.88(\mathrm{dt}, J=18.6,6.6 \mathrm{~Hz}, 3 \mathrm{H}) ;{ }^{13} \mathrm{C} \mathrm{NMR}(101$ MHz, Chloroform-d) $\delta 163.24,163.20,160.30,157.86,130.41,130.07,128.77,128.68,126.44,121.37$, 121.25, 119.54, 116.83, 116.57, 110.27, 106.55, 40.28, 31.87, 29.54, 29.33, 29.27, 27.06, 22.72, 14.16; HRMS-EI: $\mathrm{m} / \mathrm{z}[\mathrm{M}]^{+}$calcd for $\mathrm{C}_{19} \mathrm{H}_{25} \mathrm{~N}_{2} \mathrm{O}: 316.1951$; found: 316.1953

\section{2-chloro-N-octyl-5-(1H-pyrrol-2-yl)benzamide (2g)}

The titled compound was obtained by following the above general procedure of $2 \mathbf{a}(139 \mathrm{mg}, 75 \%) .{ }^{1} \mathrm{H}$ NMR (400 MHz, Chloroform-d) $\delta 8.58(\mathrm{bs}, 1 \mathrm{H}), 7.75(\mathrm{dd}, J=1.8,1.8 \mathrm{~Hz}, 1 \mathrm{H}), 7.56(\mathrm{dd}, J=1.8,1.8 \mathrm{~Hz}$, $1 \mathrm{H}), 7.43(\mathrm{dd}, J=1.8,1.8 \mathrm{~Hz}, 1 \mathrm{H}), 6.89(\mathrm{td}, J=2.7,1.4 \mathrm{~Hz}, 1 \mathrm{H}), 6.59(\mathrm{~m}, 1 \mathrm{H}), 6.30(\mathrm{~m}, 1 \mathrm{H}), 6.06(\mathrm{bs}$, $1 \mathrm{H}), 3.44(\mathrm{td}, J=7.3,5.7 \mathrm{~Hz}, 2 \mathrm{H}), 1.60(\mathrm{tt}, J=7.3,7.3 \mathrm{~Hz}, 2 \mathrm{H}), 1.44-1.15(\mathrm{~m}, 10 \mathrm{H}), 0.87(\mathrm{t}, J=6.7$ $\mathrm{Hz}, 3 \mathrm{H}) ;{ }^{13} \mathrm{C}$ NMR $(101 \mathrm{MHz}$, Chloroform-d) $\delta 166.81,136.83,135.12,135.07,129.93,126.52,123.73$, 120.52, 120.33, 110.39, 107.55, 40.51, 31.87, 29.64, 29.36, 29.28, 27.09, 22.72, 14.16; HRMS-EI: m/z $[\mathrm{M}]^{+}$calcd for $\mathrm{C}_{19} \mathrm{H}_{25} \mathrm{ClN}_{2} \mathrm{O}: 332.1655$; found: 332.1658

\section{3-fluoro-N-octyl-5-(1H-pyrrol-2-yl)benzamide (2h)}

The titled compound was obtained by following the above general procedure of $\mathbf{2 a}(82 \mathrm{mg}, 70 \%) .{ }^{1} \mathrm{H}$ NMR (400 MHz, Chloroform- $d$ ) $\delta 8.60$ (bs, 1H), $7.65(\mathrm{dd}, J=1.4 \mathrm{~Hz}, 1 \mathrm{H}), 7.28(\mathrm{~m}, 1 \mathrm{H}), 7.17$ (ddd, $J=$ $8.9,2.5,1.4 \mathrm{~Hz}, 1 \mathrm{H}), 6.89(\mathrm{td}, J=2.8,1.4 \mathrm{~Hz}, 1 \mathrm{H}), 6.58(\mathrm{~m}, 1 \mathrm{H}), 6.30(\mathrm{dd}, J=2.8,2.8 \mathrm{~Hz}, 1 \mathrm{H}), 6.07$ (bs, $1 \mathrm{H}), 3.44(\mathrm{td}, J=7.3,5.6 \mathrm{~Hz}, 2 \mathrm{H}), 1.60(\mathrm{tt}, J=7.37 .3 \mathrm{~Hz}, 4 \mathrm{H}), 1.45-1.09(\mathrm{~m}, 10 \mathrm{H}), 0.88(\mathrm{t}, J=6.8 \mathrm{~Hz}$, $3 \mathrm{H}) ;{ }^{13} \mathrm{C}$ NMR $(101 \mathrm{MHz}$, Chloroform-d) $\delta 166.71,164.41,161.96,137.40,137.32,135.64,135.55$, $130.21,120.22,117.96,113.57,113.35,111.00,110.77,110.46,107.59,40.46,31.87,29.66,29.35$, 29.27, 27.07, 22.71, 14.16; HRMS-EI: m/z [M] ${ }^{+}$calcd for $\mathrm{C}_{19} \mathrm{H}_{25} \mathrm{~N}_{2} \mathrm{O}: 316.1951$; found: 316.1952 


\section{Chloride Binding Constants by ${ }^{1} \mathrm{H}$ NMR titrations}

Upon addition of incremental amounts of $\mathrm{Cl}^{-}$anion to the solution of each ion transporter (from 0.5 equiv. to 16 equiv. of the anion), ${ }^{1} \mathrm{H}$ NMR chemical shift change of each transporter $\left(4.0 \times 10^{-3} \mathrm{M}\right.$ of each transporter was used, unless otherwise stated) were recorded in $\mathrm{CD}_{3} \mathrm{CN}$. Equilibrium constants of complexes were calculated using the equation, $\mathrm{y}=(1+\mathrm{b} \times \mathrm{x} \times K) /(1+\mathrm{x} \times K)$, where $\mathrm{x}=[\mathrm{Cl}], \mathrm{y}=\delta-$ $\delta_{o}(\delta$ is the $\mathrm{NH}$ (or $\mathrm{CH})$ chemical shift of each transporter at a certain concentration of anion and $\delta_{\mathrm{o}}$ is the $\mathrm{NH}$ (or $\mathrm{CH}$ ) chemical shift of each transporter without anion).

Table S1 Chloride binding constants $\left(K_{\mathrm{a}} ; \mathrm{M}^{-1}\right)$ of $\mathbf{2 a - 2 h}$ obtained by ${ }^{1} \mathrm{H}$ NMR titrations in $\mathrm{CD}_{3} \mathrm{CN}$ at $25{ }^{\circ} \mathrm{C}$.

\begin{tabular}{lllllll}
\hline & Pyrrolic NH & Error (\%) & $\begin{array}{l}\text { Aromatic } \\
\text { CH }\end{array}$ & Error (\%) & Amidic NH & Error (\%) \\
\hline $\mathbf{2 c}$ & 114 & 7.9 & 112 & 7.6 & 116 & 7.0 \\
$\mathbf{2 e}$ & 60 & 3.8 & 54 & 2.3 & 54 & 3.1 \\
$\mathbf{2 f}$ & 43 & 2.4 & 37 & 4.7 & 56 & 4.8 \\
$\mathbf{2 g}$ & 238 & 7.9 & 248 & 7.8 & 248 & 8.7 \\
$\mathbf{2 h}$ & 213 & 8.7 & 220 & 8.6 & 215 & 8.1 \\
\hline
\end{tabular}


(a)

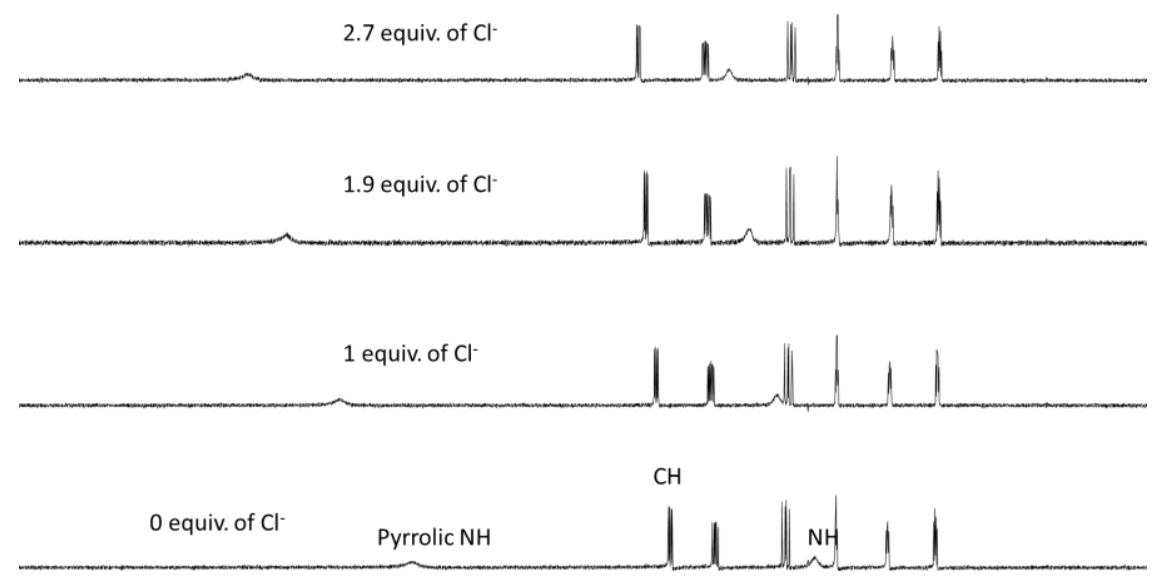

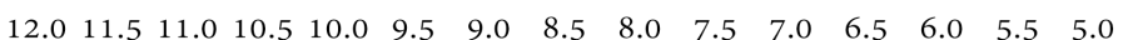

(b)

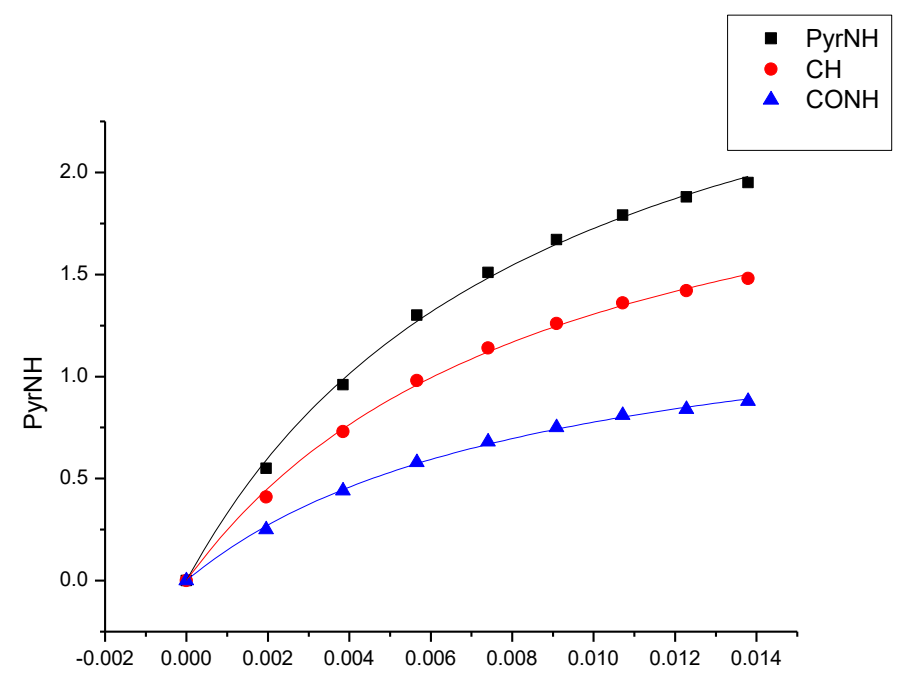

\begin{tabular}{l|r|r|r|}
\hline \hline Model & \multicolumn{2}{|l|}{ TO1 (User) } & \\
\hline Equation & $\mathrm{y}=(\mathrm{b} * \mathrm{x}) /(1+(\mathrm{K} * \mathrm{x}))$ & \\
\hline $\begin{array}{l}\text { Reduced } \\
\text { Chi-Sqr }\end{array}$ & $8.04028 \mathrm{E}-4$ & $4.41746 \mathrm{E}-4$ & $1.24306 \mathrm{E}-4$ \\
\hline Adj. R-Square & 0.99819 & 0.99827 & 0.99861 \\
\hline & & Value & Standard Error \\
\hline \multirow{2}{*}{ PyrNH } & $\mathrm{b}$ & 368.83374 & 13.40187 \\
\hline \multirow{2}{*}{$\mathrm{CH}$} & $\mathrm{k}$ & 113.74292 & 7.86303 \\
\hline \multirow{2}{*}{$\mathrm{CONH}$} & $\mathrm{b}$ & 276.75002 & 9.82011 \\
\hline & $\mathrm{k}$ & 111.91581 & 7.60719 \\
\hline & $\mathrm{b}$ & 167.59189 & 5.33782 \\
\hline & $\mathrm{k}$ & 115.80363 & 6.96462 \\
\hline
\end{tabular}

$[\mathrm{G}]$

Figure S1. (a) ${ }^{1} \mathrm{H}$ NMR titrations of $2 \mathrm{c}$ with $\mathrm{TBACl}$ in $\mathrm{CD}_{3} \mathrm{CN}$ at $25^{\circ} \mathrm{C}(400 \mathrm{MHz}$ ). (b) Curve-fitting trace ploted from the changed chemical shift values of pyrrolic $\mathrm{NH}$, aromatic $\mathrm{CH}$, and amidic $\mathrm{NH}$ in figure S1a. 
(a)

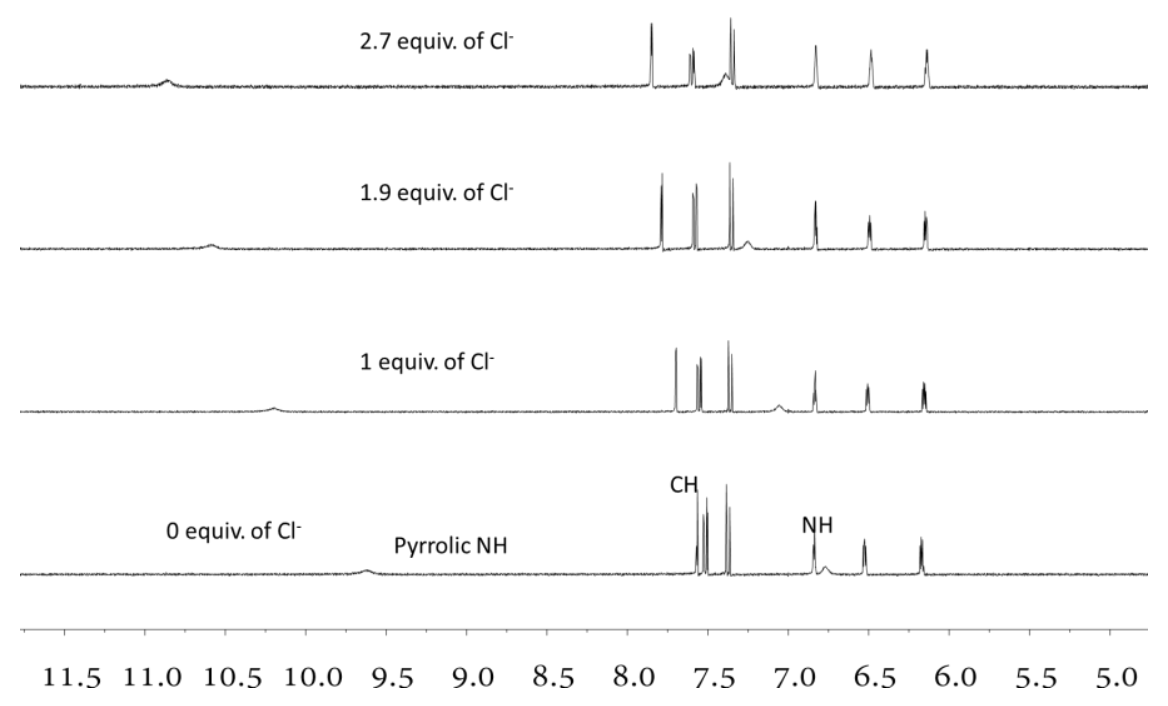

(b)

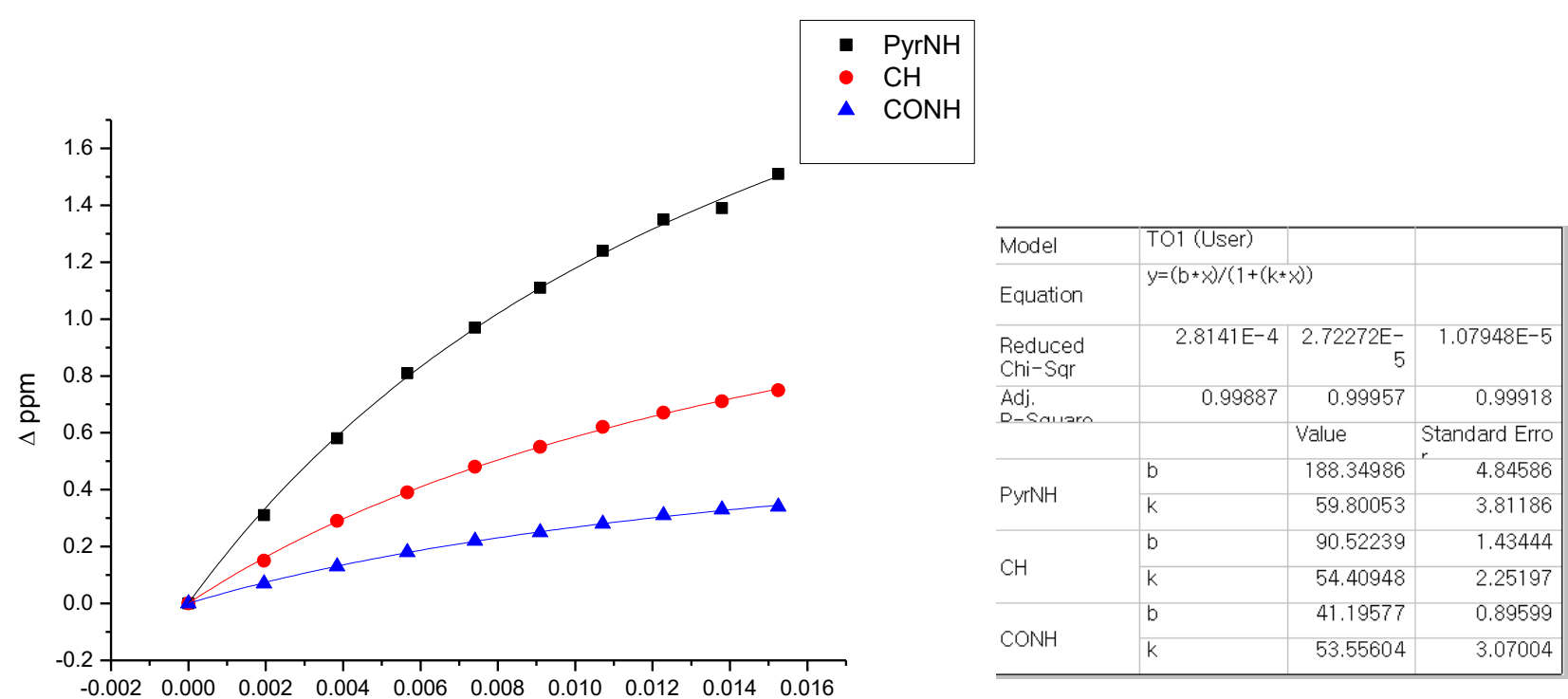

$[\mathrm{G}]$

Figure S2. (a) ${ }^{1} \mathrm{H}$ NMR titrations of $2 \mathrm{e}$ with $\mathrm{TBACl}$ in $\mathrm{CD}_{3} \mathrm{CN}$ at $25^{\circ} \mathrm{C}(400 \mathrm{MHz}$ ). (b) Curve-fitting traces ploted from the changed chemical shift values of pyrrolic $\mathrm{NH}$, aromatic $\mathrm{CH}$, and amidic $\mathrm{NH}$ in figure S2a. 
(a)

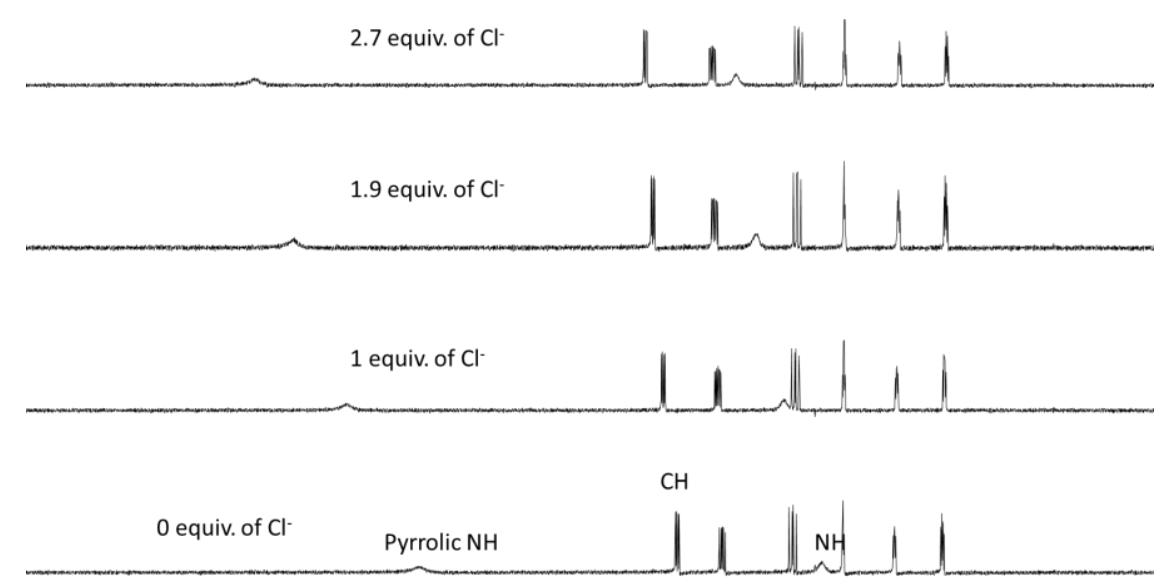

$\begin{array}{lllllllllllllll}12.0 & 11.5 & 11.0 & 10.5 & 10.0 & 9.5 & 9.0 & 8.5 & 8.0 & 7.5 & 7.0 & 6.5 & 6.0 & 5.5 & 5.0\end{array}$

(b)

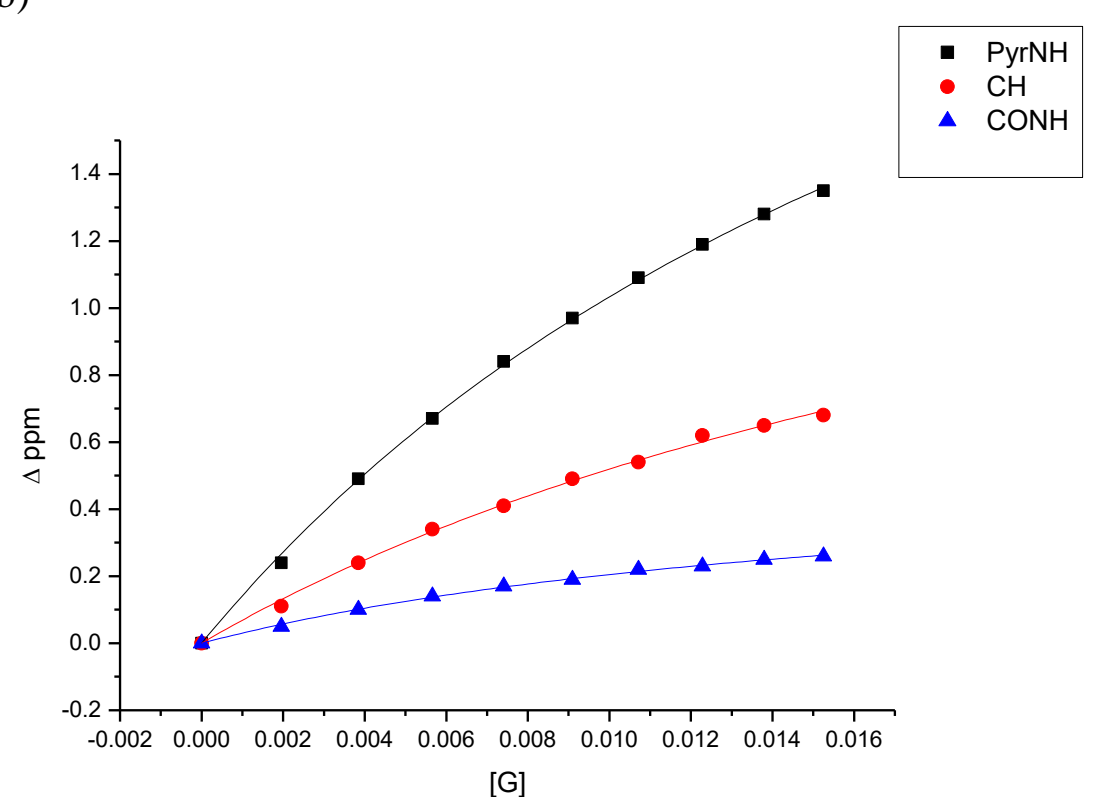

\begin{tabular}{|c|c|c|c|}
\hline Model & T01 (User) & & \\
\hline Equation & \multicolumn{2}{|l|}{$y=(b * x) /(1+(k * x))$} & \\
\hline $\begin{array}{l}\text { Reduced } \\
\text { Chi-Sar }\end{array}$ & $1.2963 \mathrm{E}-4$ & $1.36775 \mathrm{E}-4$ & $1.45075 \mathrm{E}-5$ \\
\hline \multirow[t]{2}{*}{ Adj. R-Square } & 0.99937 & 0.99749 & 0.99812 \\
\hline & & Value & Standard Error \\
\hline \multirow[b]{2}{*}{ PyrNH } & $\mathrm{b}$ & 147.85537 & 2.80116 \\
\hline & k & 43.0886 & 2.45076 \\
\hline \multirow[b]{2}{*}{$\mathrm{CH}$} & b & 71.38164 & 2.71038 \\
\hline & k & 37.40007 & 4.66729 \\
\hline \multirow[b]{2}{*}{$\mathrm{CONH}$} & $b$ & 32.02367 & 1.06525 \\
\hline & k & 56.25745 & 4.79632 \\
\hline
\end{tabular}

Figure S3. (a) ${ }^{1} \mathrm{H}$ NMR titrations of $2 \mathbf{f}$ with $\mathrm{TBACl}$ in $\mathrm{CD}_{3} \mathrm{CN}$ at $25^{\circ} \mathrm{C}(400 \mathrm{MHz})$. (b) Curve-fitting traces ploted from the changed chemical shift values of pyrrolic $\mathrm{NH}$, aromatic $\mathrm{CH}$, and amidic $\mathrm{NH}$ in figure S3a. 
(a)

5 equiv. of $\mathrm{Cl}$

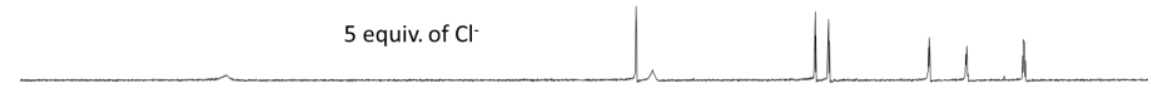

3 equiv. of $\mathrm{Cl}^{-}$
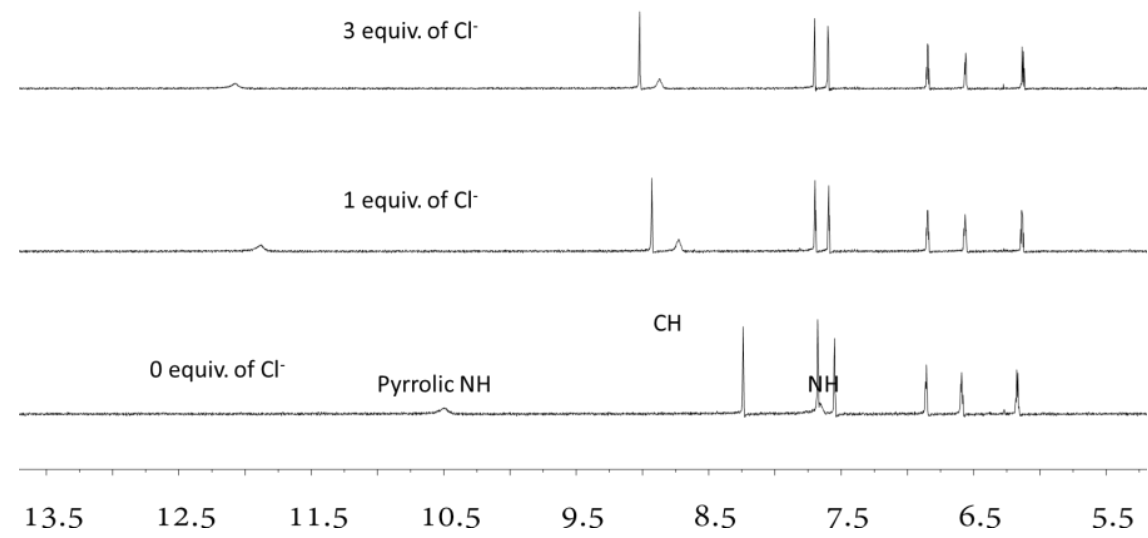

(b)

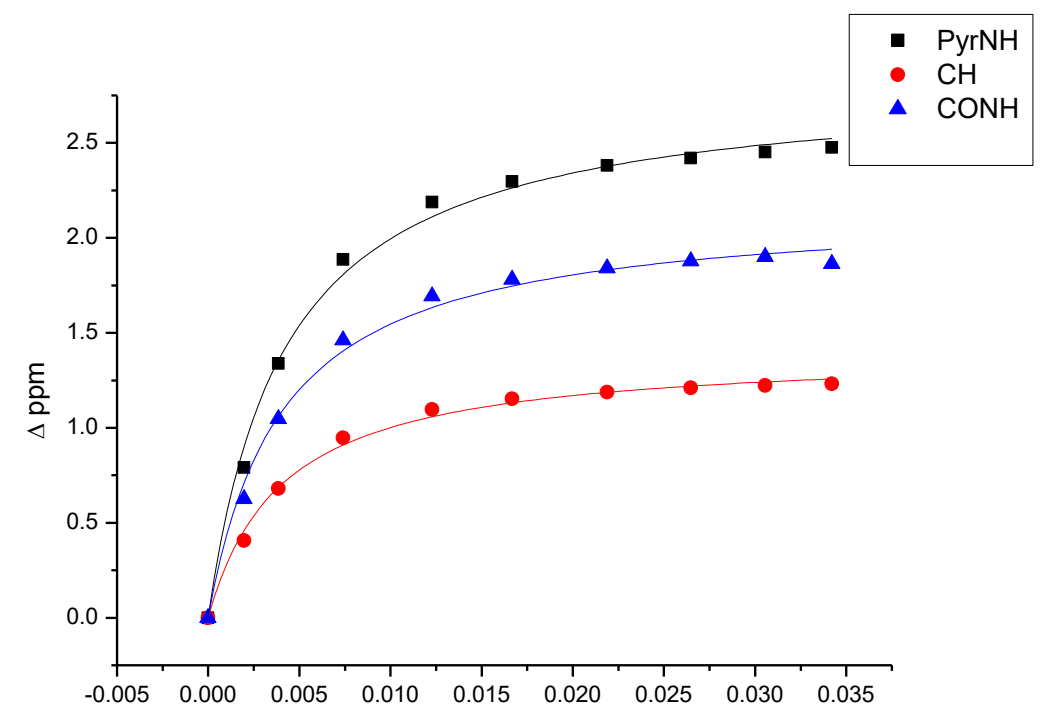

\begin{tabular}{|c|c|c|c|}
\hline Model & \multirow{2}{*}{\multicolumn{2}{|c|}{$\begin{array}{l}\text { T01 (User) } \\
y=(b+x) /(1+(k+x))\end{array}$}} & \multirow[b]{3}{*}{0.00268} \\
\hline Equation & & & \\
\hline $\begin{array}{l}\text { Reduced } \\
\text { Chi-Sar }\end{array}$ & 0.00377 & $\begin{array}{r}9.15326 \mathrm{E}- \\
4\end{array}$ & \\
\hline Adj. R-Square & 0.99476 & 0.99484 & 0.99367 \\
\hline 1 & & Value & Standard Erro \\
\hline \multirow{2}{*}{ PYNH } & b & 673.76696 & 43.18026 \\
\hline & k & 237.77145 & 18.96454 \\
\hline \multirow[b]{2}{*}{$\mathrm{CH}$} & b & 348.11735 & 22.17313 \\
\hline & k & 247.60772 & 19.5186 \\
\hline \multirow[b]{2}{*}{$\mathrm{CONH}$} & $b$ & 538.63122 & 38.05451 \\
\hline & k & 248.41304 & 21.71106 \\
\hline
\end{tabular}

[G]

Figure S4. (a) ${ }^{1} \mathrm{H}$ NMR titrations of $2 \mathrm{~g}$ with $\mathrm{TBACl}$ in $\mathrm{CD}_{3} \mathrm{CN}$ at $25{ }^{\circ} \mathrm{C}(400 \mathrm{MHz}$ ). (b) Curve-fitting traces ploted from the changed chemical shift values of pyrrolic $\mathrm{NH}$, aromatic $\mathrm{CH}$, and amidic $\mathrm{NH}$ in figure S4a. 
(a)

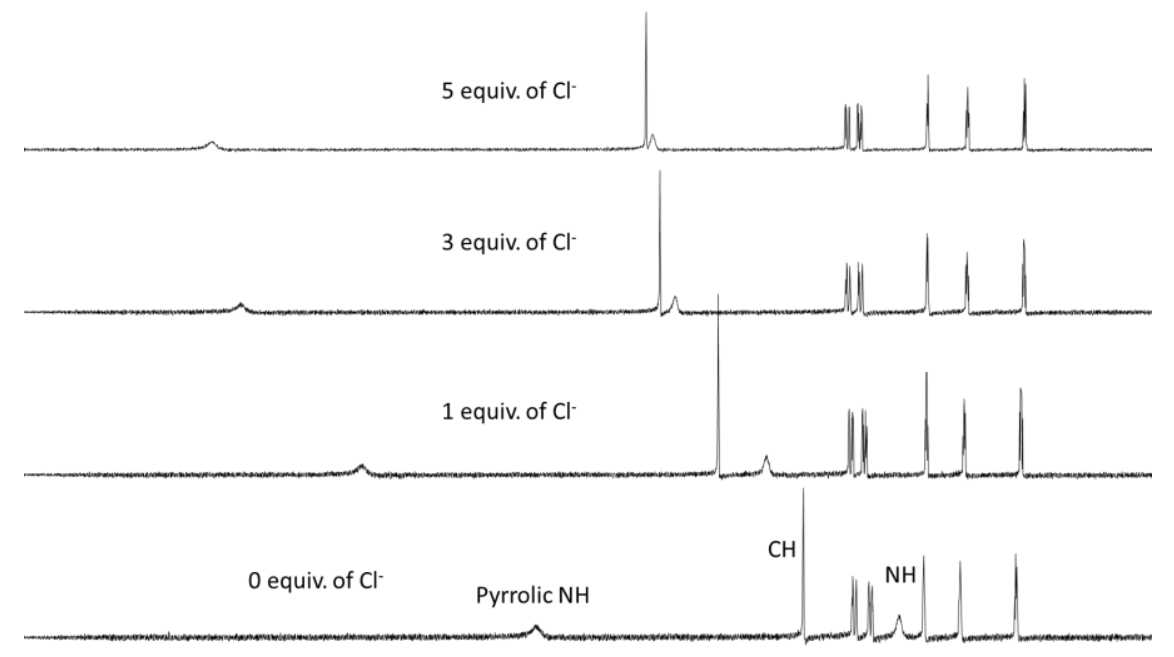

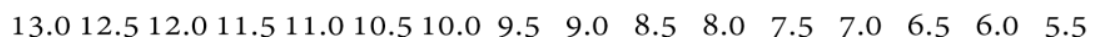

(b)

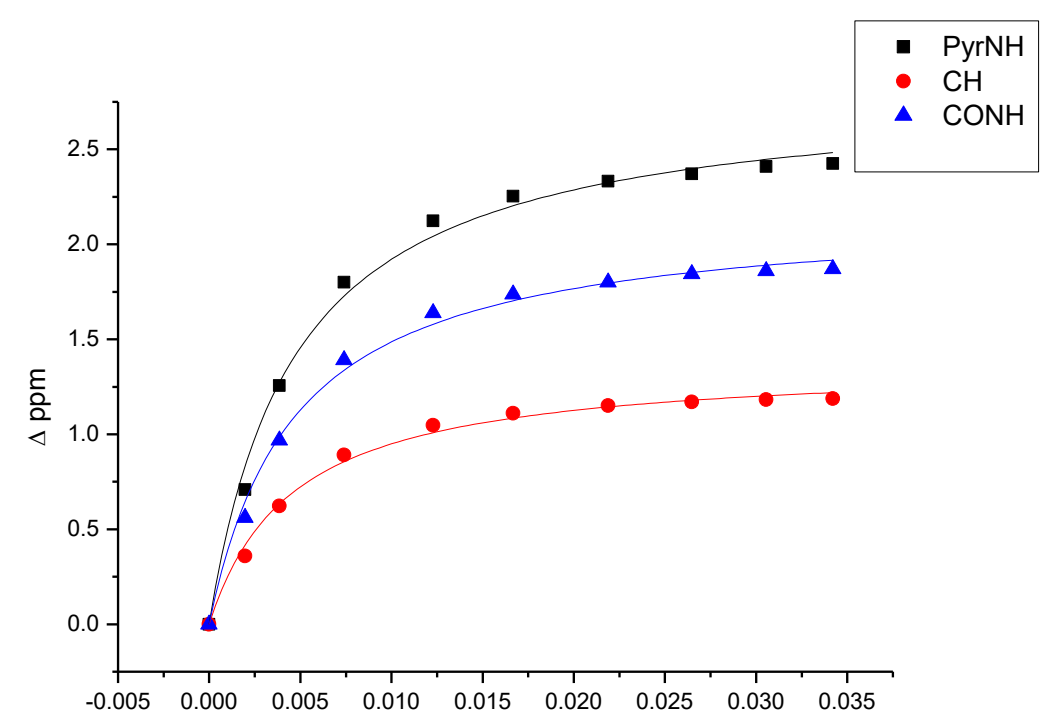

\begin{tabular}{|c|c|c|c|}
\hline Model & T01 (User) & & \\
\hline Equation & \multicolumn{2}{|c|}{$y=(b * x) /(1+(k * x))$} & \\
\hline $\begin{array}{l}\text { Reduced } \\
\text { Chi-Sqr }\end{array}$ & 0.00444 & 0.00103 & 0.00228 \\
\hline Adj. R-Square & 0.99375 & 0.99397 & 0.9946 \\
\hline I & & Value & Standard Error \\
\hline \multirow{2}{*}{ PyrNH } & b & 601.66346 & 41.93582 \\
\hline & k & 213.14891 & 18.78517 \\
\hline \multirow{2}{*}{$\mathrm{CH}$} & b & 303.47637 & 20.79464 \\
\hline & k & 219.60746 & 18.94256 \\
\hline \multirow[b]{2}{*}{$\mathrm{CONH}$} & b & 467.85476 & 30.28172 \\
\hline & k & 214.82059 & 17.56044 \\
\hline
\end{tabular}

$[\mathrm{G}]$

Figure S5. (a) ${ }^{1} \mathrm{H}$ NMR titrations of $\mathbf{2 h}$ with $\mathrm{TBACl}$ in $\mathrm{CD}_{3} \mathrm{CN}$ at $25{ }^{\circ} \mathrm{C}(400 \mathrm{MHz})$. (b) Curve-fitting traces ploted from the changed chemical shift values of pyrrolic $\mathrm{NH}$, aromatic $\mathrm{CH}$, and amidic $\mathrm{NH}$ in figure S5a. 


\section{DFT calculation}

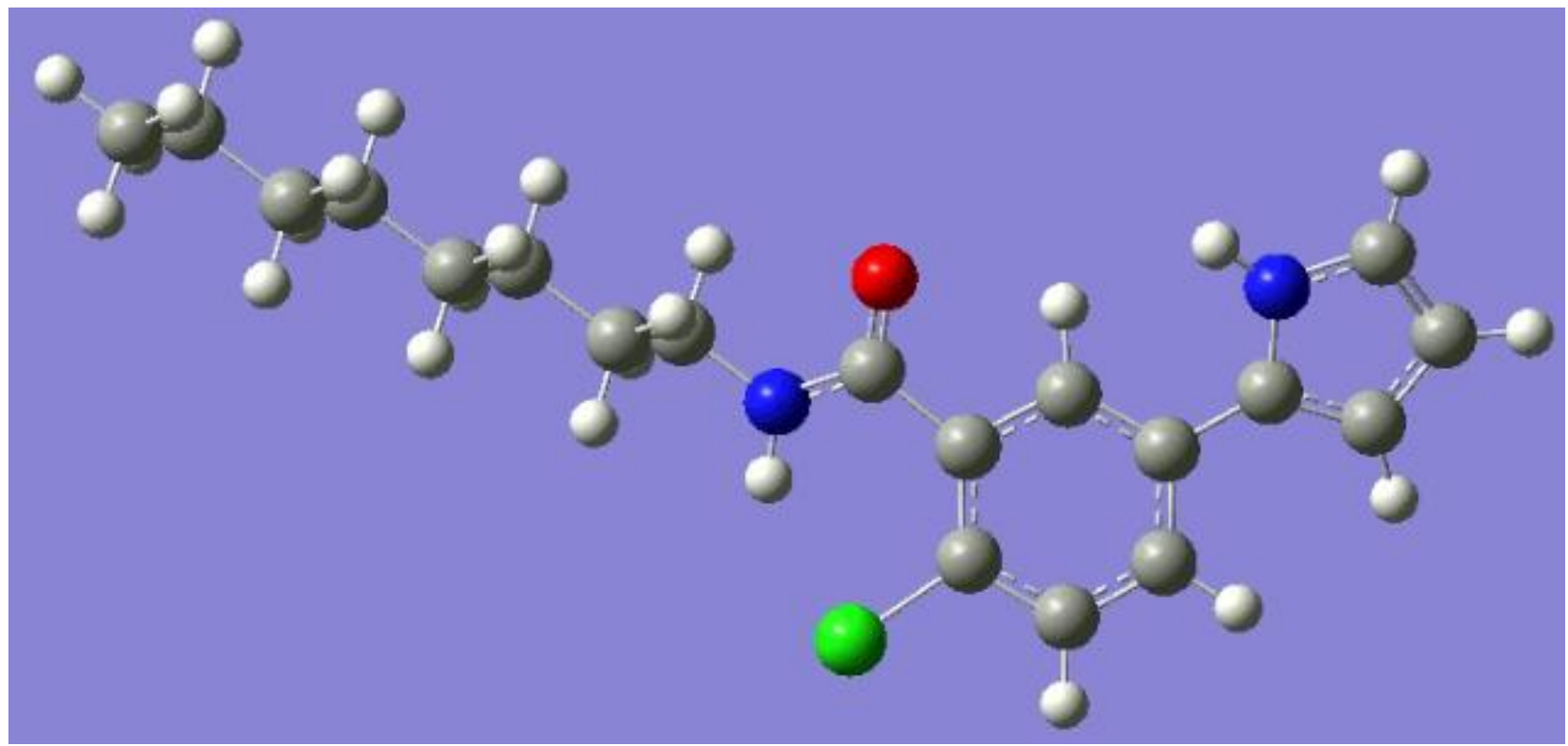

Figure S6. Optimized strcture of 2e via DFT calculation at the level of B3LYP/6-31G**

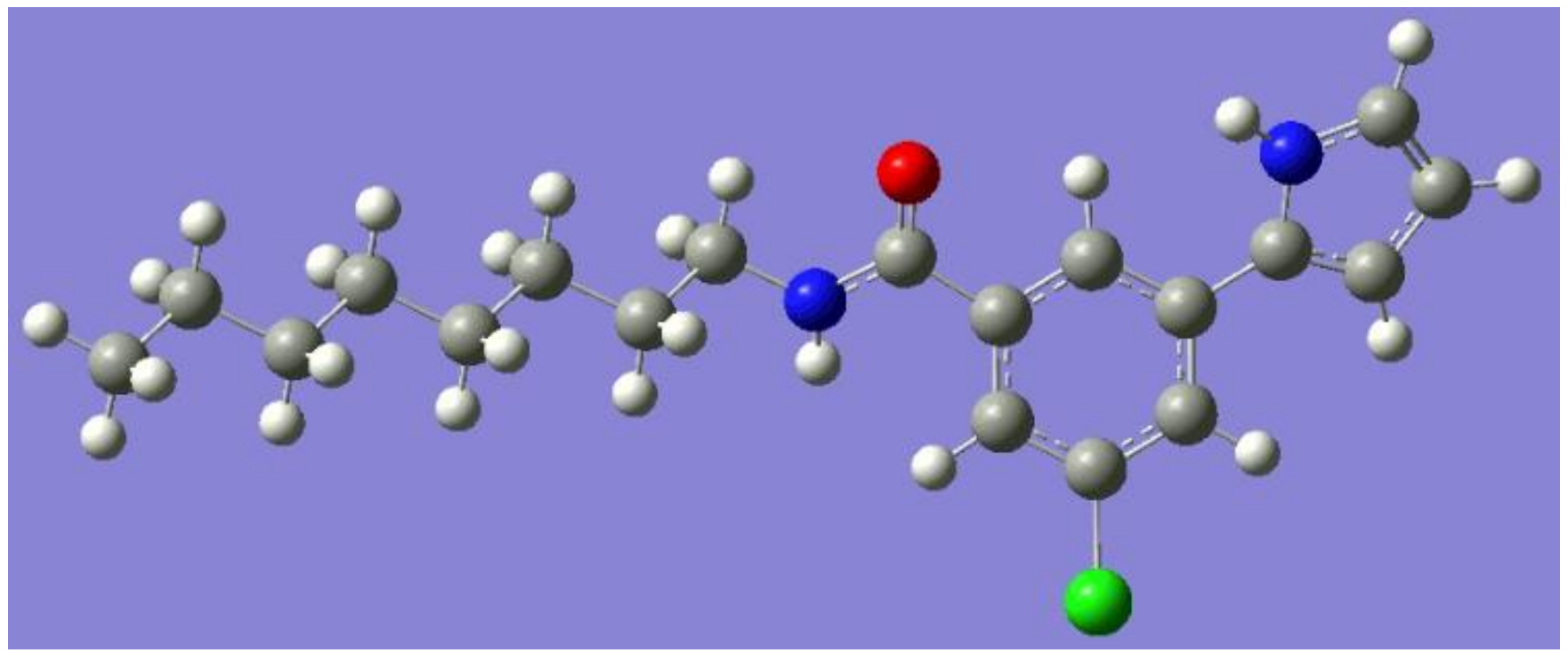

Figure S7. Optimized strcture of $\mathbf{2 g}$ via DFT calculation at the level of B3LYP/6-31G** 

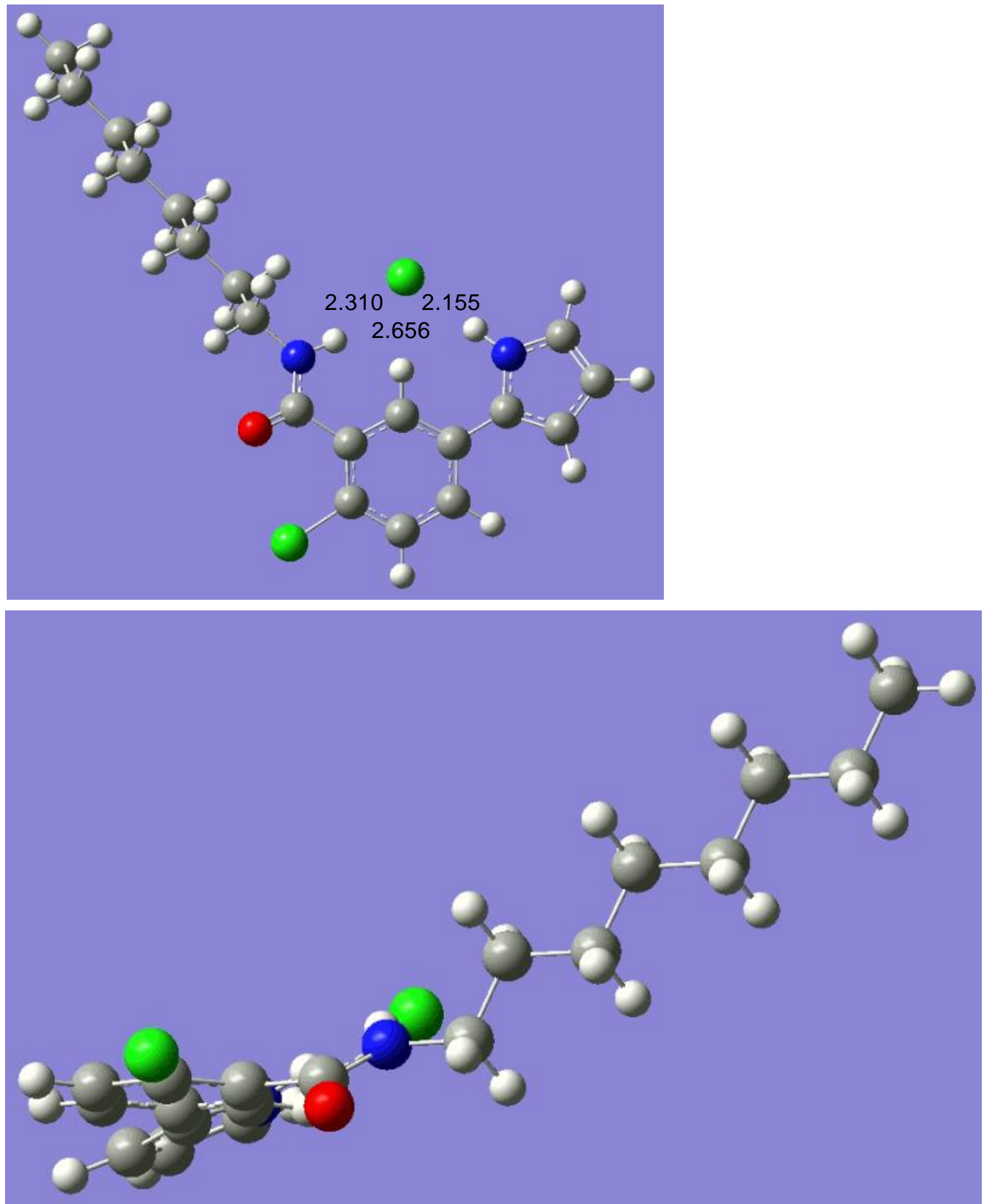

Figure S8. Optimized strcture of 2e. $\mathrm{Cl}^{-}$via DFT calculation at the level of B3LYP/6-31G** 

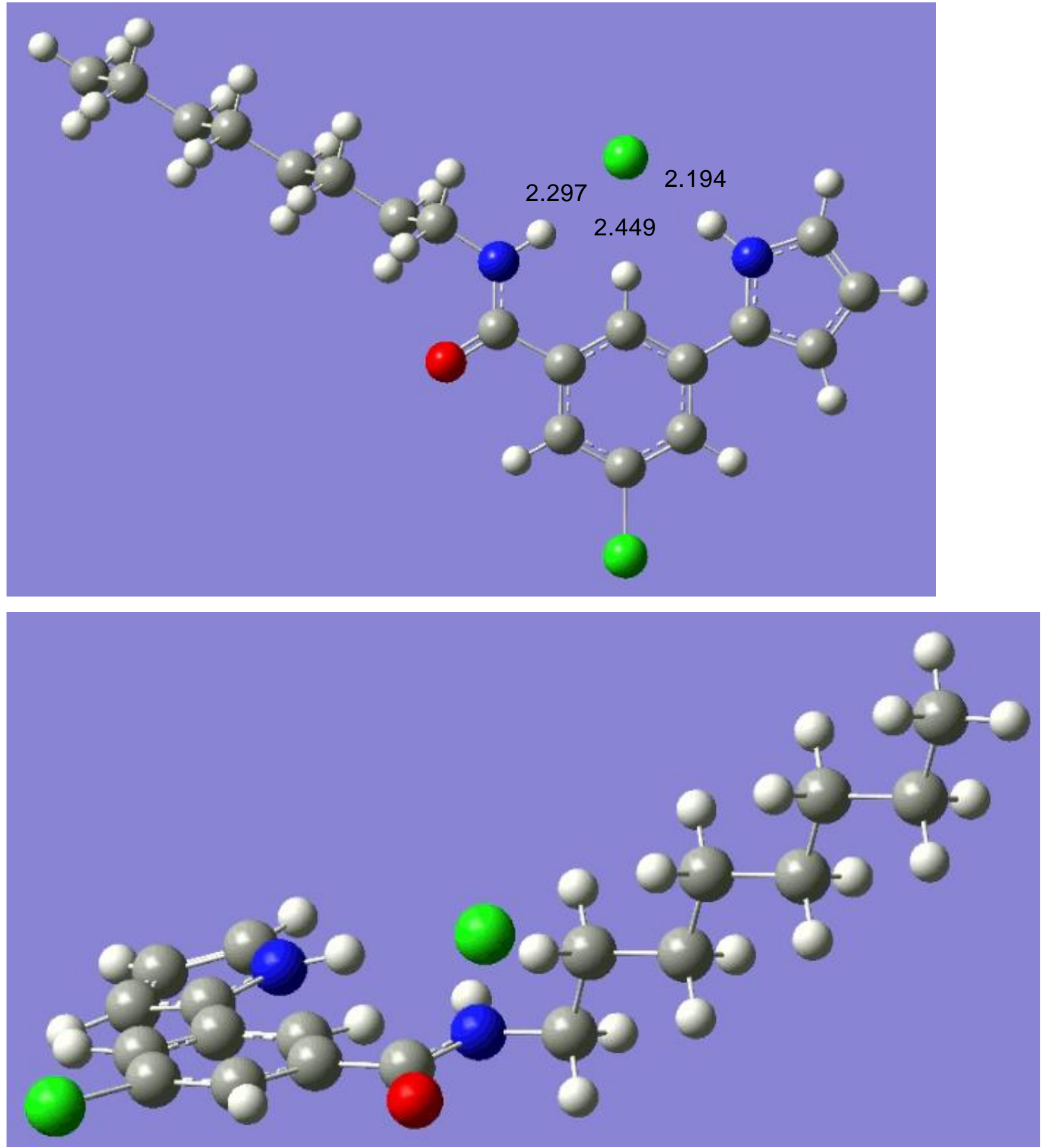

Figure S9. Optimized strcture of $\mathbf{2 g} \cdot \mathrm{Cl}^{-}$via DFT calculation at the level of B3LYP/6-31G** 


\section{Preparation of liposomes containing fluorophore}

1-palmitoyl-2-oleoyl-sn-glycero-3-phosphocholine(POPC, Avanti Polar Lipids, Alabaster, AL) was obtained as in $20 \mathrm{mg} / \mathrm{mL}$ solution in $\mathrm{CHCl}_{3}$ from). The lipid solution was dried under argon and further dried in a dessicator under vacuum overnight to fully remove chloroform. The dried lipid film was rehydrated in solution containing $475 \mathrm{mM} \mathrm{NaCl}$ and $25 \mathrm{mM}$ fluorophore 8-aminonaphthalene-1,3,6trisulfonic acid(ANTS) buffered at $\mathrm{pH} 7.2$ at room temperature overnight. The suspension was sequentially sonicated for 1-2 min in a bath sonicator (G112SPIT, Laboratory Supplies Co., Hicksville, NY), frozen-thawed for 4-5 times, and extruded 21 times at room temperature using an Avanti miniextruder with a $0.2 \mu \mathrm{m}$ polycarbonate membrane filter(Alabaster, AL), resulting in large unilamelar vesicles(LUVs) containing ANTS. The extruded suspension was dispersed in $500 \mathrm{mM} \mathrm{NaNO} 3$ buffered at $\mathrm{pH} 7.2$ (Na buffer) to 1:20 ratio and stored at $12{ }^{\circ} \mathrm{C}$ in the dark. All the LUV-ANTS stocks were not stored over 24 hours.

\section{Fluorescence spectroscopy}

The ANTS fluorescence emission was measured at $25{ }^{\circ} \mathrm{C}$ using a fluorometer. The emmision was scanned from $350 \mathrm{~nm}$ to $700 \mathrm{~nm}$ (excitation: $352 \mathrm{~nm}$ ). LUV-ANTS stock was diluted to measure fluorescence. Each LUV-ANTS stock was mixed with $\mathrm{Na}$ buffer, Tl buffer (475 $\mathrm{mM} \mathrm{NaNO} 3,25 \mathrm{mM}$ $\mathrm{TlNO}_{3}, \mathrm{pH}$ 7.2), Tl buffer with $2 \mathrm{~mol} \%$ of triton $\mathrm{X}$, respectivly to the ratio of 5:5, and a DMSO solution of $\mathbf{2 a}-\mathbf{2 h}$ (4 mol\% relative to POPC) was added. Emmision scan was conducted for each mixture after 3 min reaction.

(a)

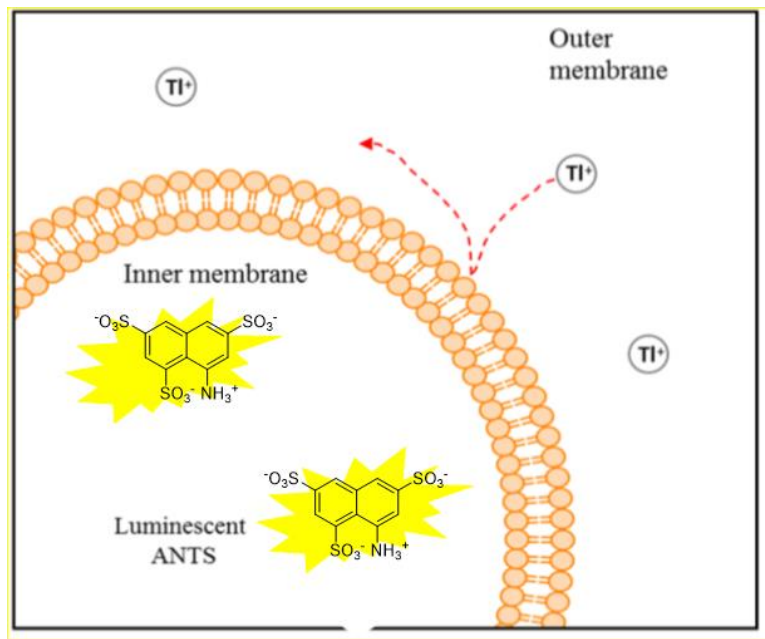

(b)

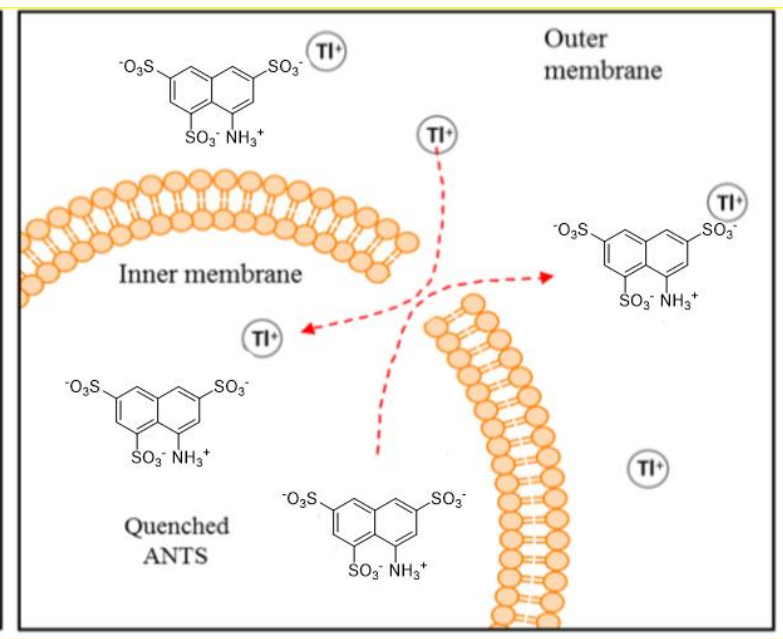

Figure S10. Schematic image of LUV-ANTS experiment in the condition that (a) compounds (2a-2h) are not involved in the rupture (or damage) of the LUV (b) compounds (2a-2h) are involved in the rupture (or damage) of the LUV. 


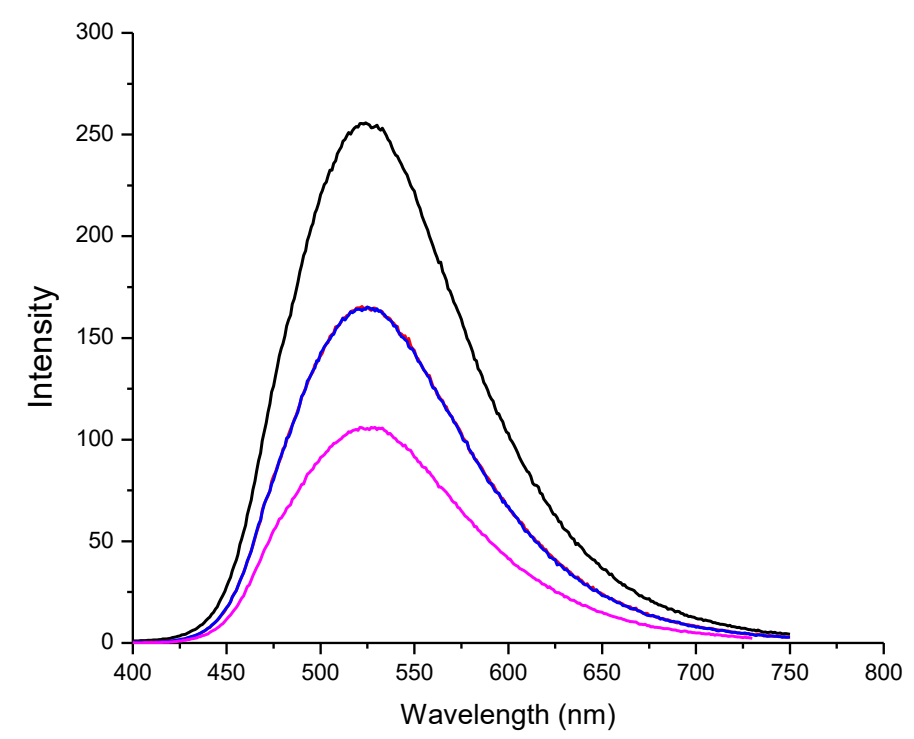

Figure S11. Fluorescence spectra of ANTS-LUV solutions in Na buffer (Black line), Tl buffer + DMSO (Red line), Tl buffer containing $4 \mathrm{~mol} \%$ of $\mathbf{2 a}$ (Blue line) and $\mathrm{Tl}^{+}$buffer containing $2 \mathrm{~mol} \%$ of triton $\mathrm{X}$ (Pink line).

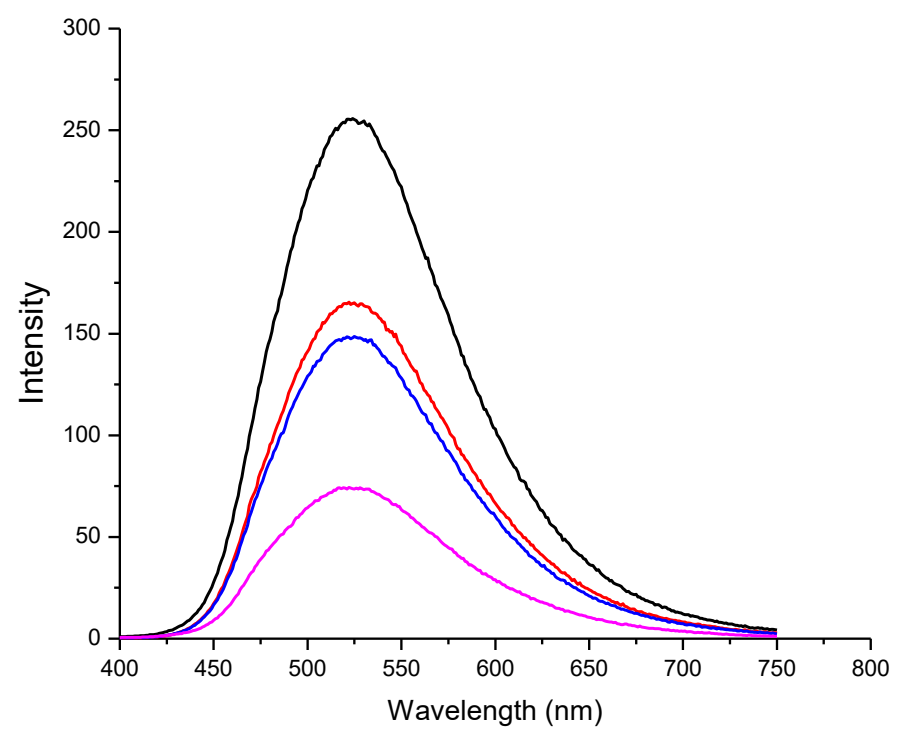

Figure S12. Fluorescence spectra of ANTS-LUV solutions in Na buffer (Black line), Tl buffer + DMSO (Red line), Tl buffer containing 4 mol\% of $\mathbf{2 b}$ (Blue line) and Tl buffer containing 2 mol\% of triton X (Pink line). 


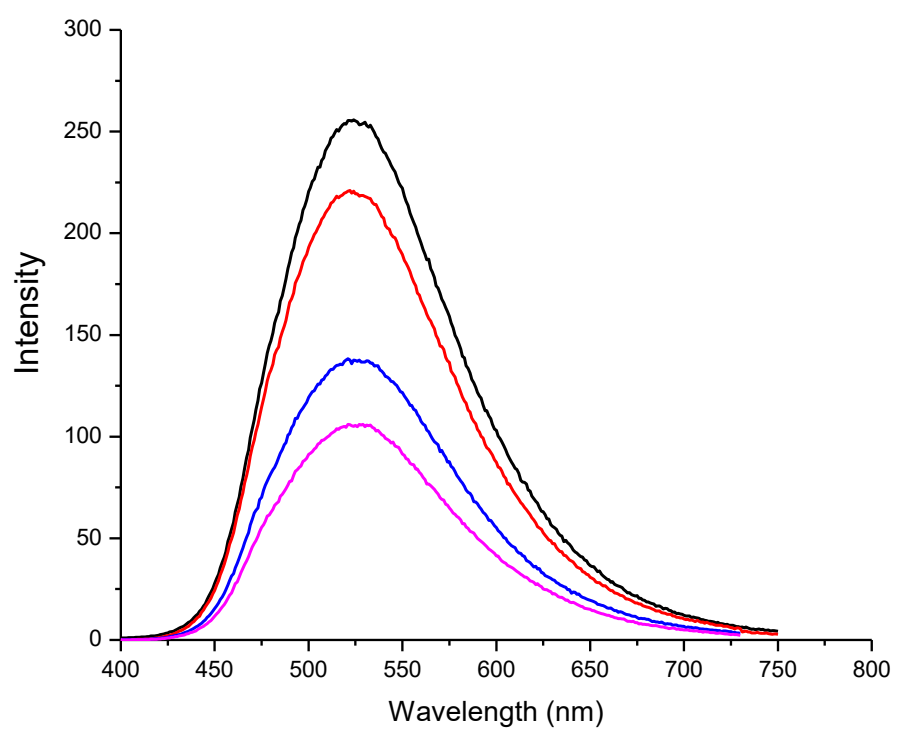

Figure S13. Fluorescence spectra of ANTS-LUV solutions in Na buffer (Black line), Tl buffer + DMSO (Red line), Tl buffer containing 4 mol\% of $2 c$ (Blue line) and Tl buffer containing 2 mol\% of triton $\mathrm{X}$ (Pink line).

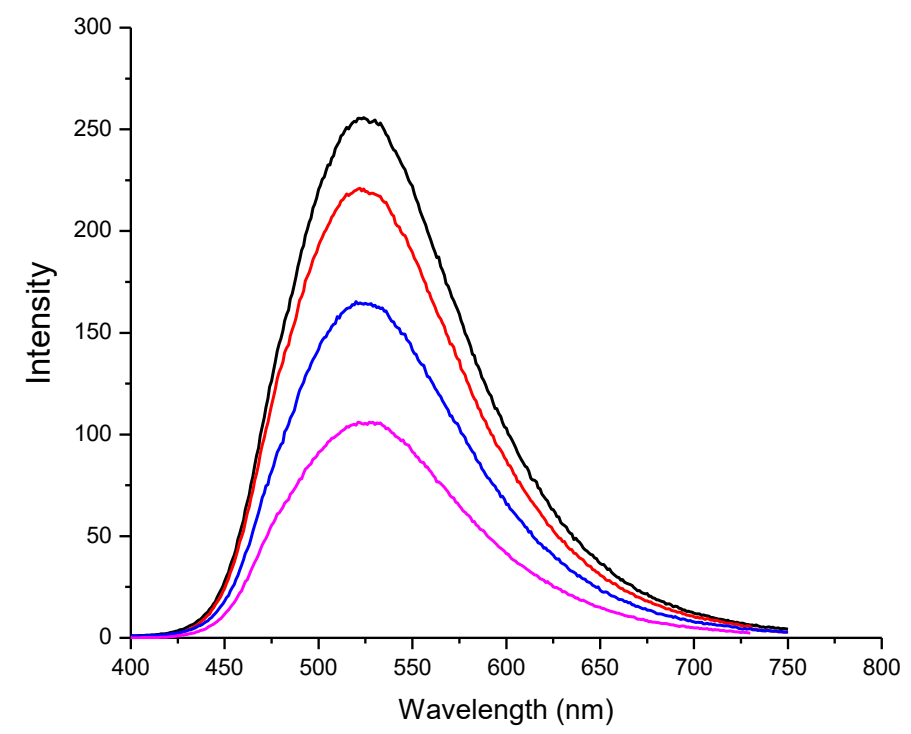

Figure S14. Fluorescence spectra of ANTS-LUV solutions in Na buffer (Black line), Tl buffer + DMSO (Red line), Tl buffer containing 4 mol\% of $2 d$ (Blue line) and $\mathrm{Tl}$ buffer containing $2 \mathrm{~mol} \%$ of triton $\mathrm{X}$ (Pink line). 


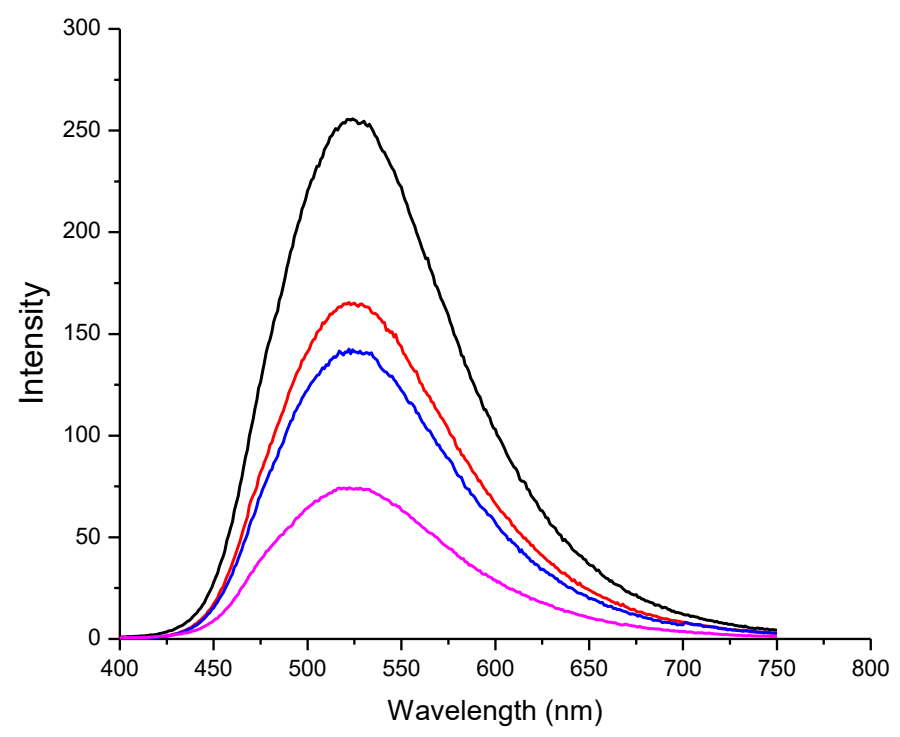

Figure S15. Fluorescence spectra of ANTS-LUV solutions in Na buffer (Black line), Tl buffer + DMSO (Red line), Tl buffer containing 4 mol\% of $2 \mathrm{e}$ (Blue line) and Tl buffer containing $2 \mathrm{~mol} \%$ of triton $\mathrm{X}$ (Pink line).

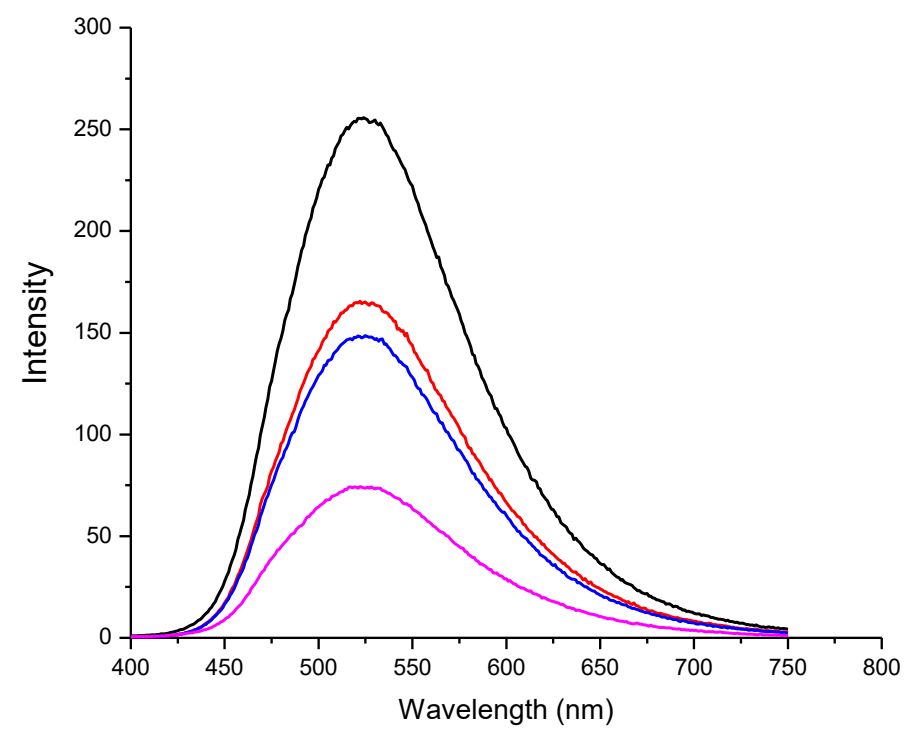

Figure S16. Fluorescence spectra of ANTS-LUV solutions in Na buffer (Black line), Tl buffer + DMSO (Red line), Tl buffer containing $4 \mathrm{~mol} \%$ of $\mathbf{2 f}$ (Blue line) and $\mathrm{Tl}$ buffer containing $2 \mathrm{~mol} \%$ of triton $\mathrm{X}$ (Pink line). 


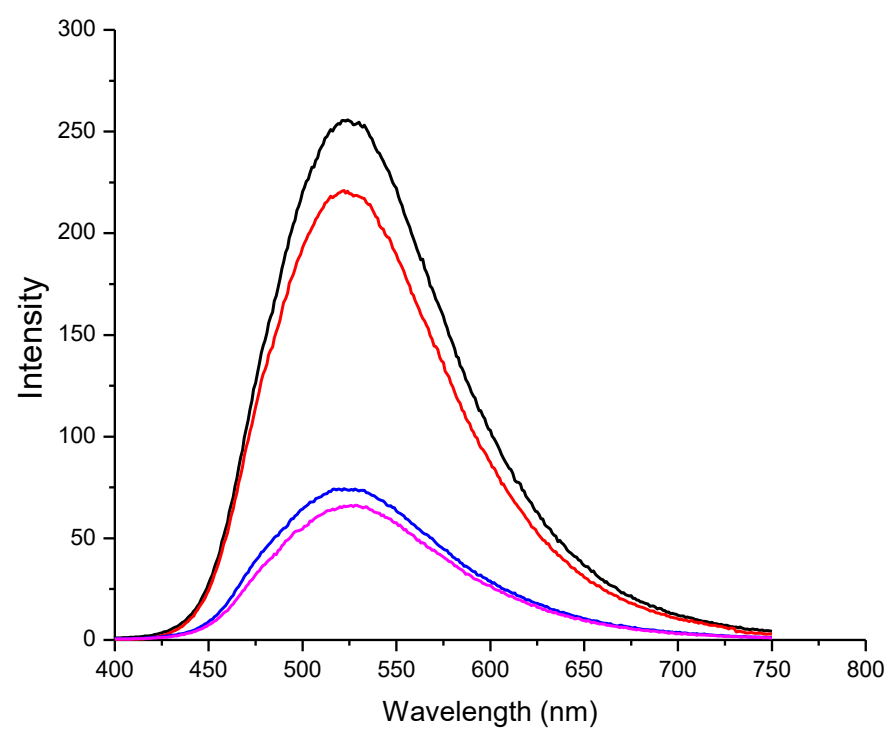

Figure S17. Fluorescence spectra of ANTS-LUV solutions in Na buffer (Black line), Tl buffer + DMSO (Red line), Tl buffer containing $4 \mathrm{~mol} \%$ of $\mathbf{2 g}$ (Blue line) and $\mathrm{Tl}$ buffer containing $2 \mathrm{~mol} \%$ of triton $\mathrm{X}$ (Pink line).

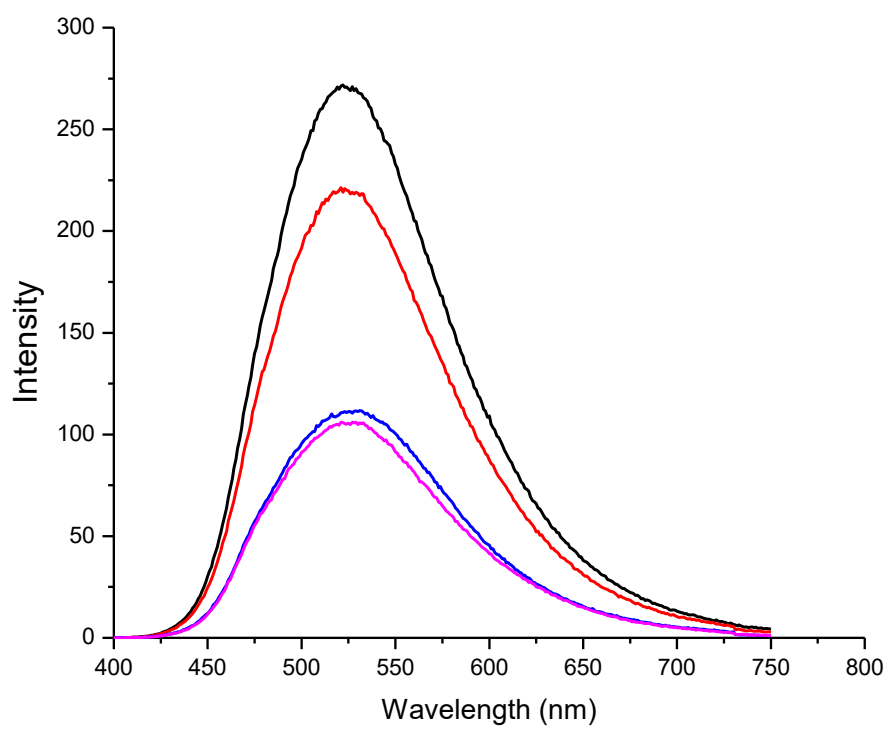

Figure S18. Fluorescence spectra of ANTS-LUV solutions in Na buffer (Black line), Tl buffer + DMSO (Red line), Tl buffer containing $4 \mathrm{~mol} \%$ of $\mathbf{2 h}$ (Blue line) and $\mathrm{Tl}$ buffer containing $2 \mathrm{~mol} \%$ of of triton $\mathrm{X}$ (Pink line). 


\section{Preparation of POPC Vesicles}

A lipid film of 1-palmitoyl-2-oleoyl-sn-glycero-3-phosphocholine (POPC) was formed from chloroform solution $(20 \mathrm{mg} / \mathrm{mL})$ under the gentle stream of nitrogen gas and dried under vacuum for at least 2 hours. The lipid film was then rehydrated in buffer solution $(488 \mathrm{mM} \mathrm{NaCl}$ and $5 \mathrm{mM}$ phosphate buffer, $\mathrm{pH}$ 7.2) and the solution was vortexed. The lipid suspension was then subjected to seven freeze-thaw cycles and left at room temperature for 30 minutes, followed by extrusion through a $200 \mathrm{~nm}$ polycarbonate membrane 31 times. The resulting unilamellar vesicles were dialyzed to remove unencapsulated $\mathrm{NaCl}$ salts.

\section{Chloride Transport Assays}

Unilamellar POPC vesicles, prepared as described above, were suspended in $488 \mathrm{mM} \mathrm{NaNO} 3$ solution buffered at $\mathrm{pH} 7.2$ with $5 \mathrm{mM}$ sodium phosphate salts. The lipid concentration of each sample was $1 \mathrm{mM}$. The carrier molecules dissolved in DMSO (4 mol\%) were added to monitor chloride efflux using a chloride selective electrode. At $10 \mathrm{~min}, 10 \%$ Triton-X was added to rupture the vesicles to obtain the final concentration of $\mathrm{Cl}^{-}$.

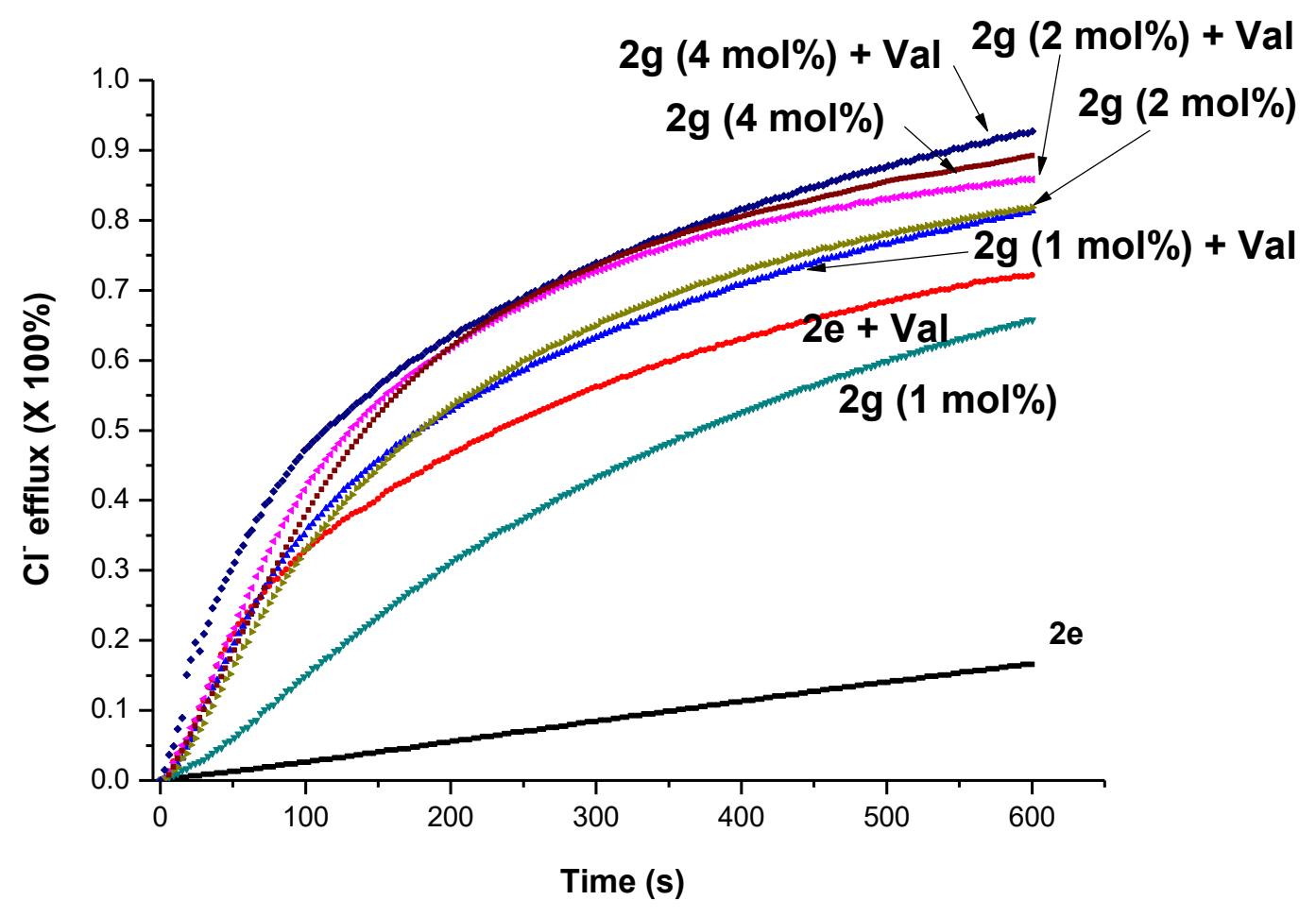

Figure S19. Chloride efflux activity of $\mathbf{2 e}$ ( 4 mol\% relative to POPC) and $\mathbf{2 g}(1,2$, and 4 mol\% relative to POPC) was examined with or without $125 \mathrm{nM}$ of valinomycin (Val). The vesicles contained $\mathrm{KCl}$ (488 $\mathrm{mM}$ ) and were immersed in $\mathrm{NaNO}_{3}(488 \mathrm{mM}), \mathrm{pH} 7.0$ solution; at 600 seconds, they were lysed to obtain $100 \%$ chloride efflux. 


\section{Electrical measurement across lipid bilayer membranes}

A lipid bilayer membrane was reconstructed using a conventional method in $\sim 100 \mu \mathrm{m}$ aperture that was made using a spark generator (DAEDALON) on a $10 \mu \mathrm{m}$ thick PTFE film (Good Fellow). DPhPC (1,2diphytanoyl-sn-glycero-3-phosphocholine, Avanti Polar Lipid, Inc.) dissolved in n-decane (MP biomedicals) at concentration of $30 \mathrm{mg} / \mathrm{mL}$ was used as lipid solution. The lipid solution was pre-painted around the aperture in the PTFE film and was dried for 30 minutes. The film was placed horizontally in the chamber filled with buffer solution (1 M NaCl, $10 \mathrm{mM}$ HEPES, and $1 \mathrm{mM}$ EDTA pH 7.2). The synthetic compound was add to both chambers (cis and trans) from $20 \mu \mathrm{M}$ to $200 \mu \mathrm{M}$. Electrical measurement across lipid bilayer membrane was done using Axopatch 200b patch clamp (Molecular device). The data was acquired via $250 \mathrm{kHz}$ sampling rate with lowpass Bessel filter $1 \mathrm{kHz}$ using Clampfit 10.3 (Molecular Devices) and was analyzed using Clampex 10.3 program.

(A) $2 \mathrm{e}$

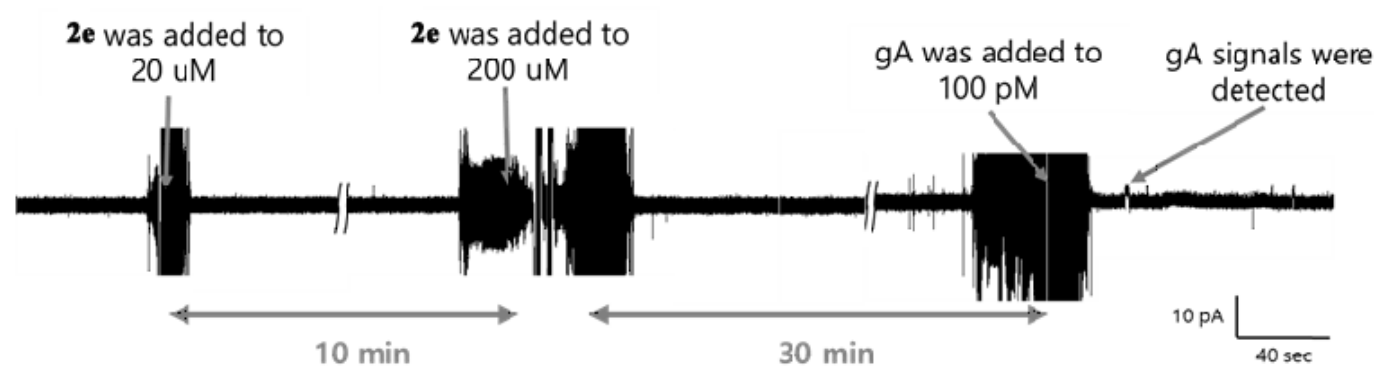

(B) $2 \mathrm{~g}$

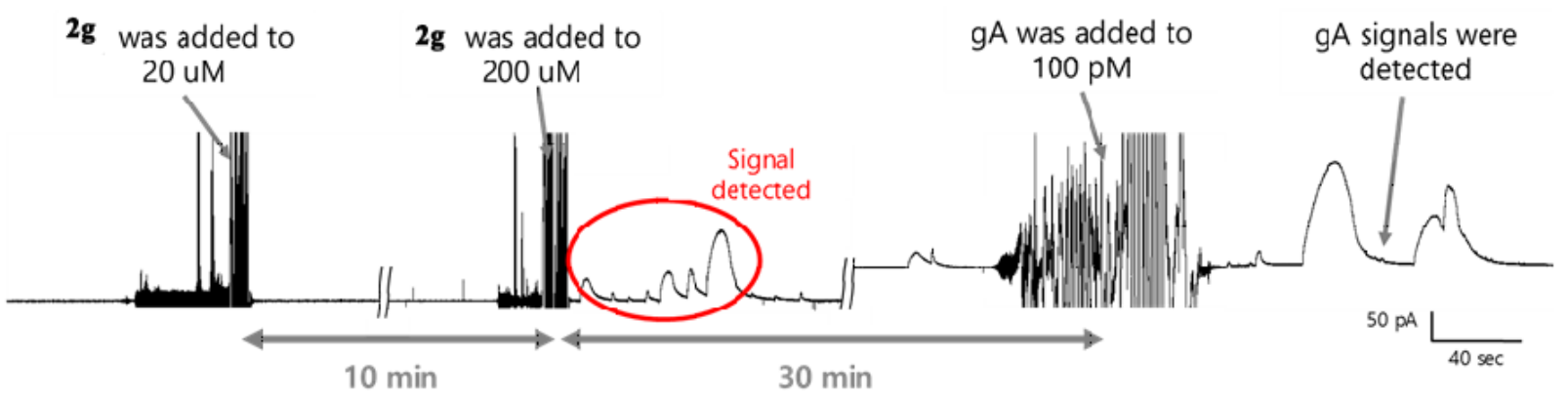

Figure S20. Electrical measurments across lipid bilayer membrane in the presence of $\mathbf{2 e}$ and $\mathbf{2 g}(20 \mu \mathrm{M}$ $200 \mu \mathrm{M}$ ). (A) $2 \mathrm{e}$ did not show any effect to the conductance of the lipid bilayers. (B) $\mathbf{2} \mathbf{g}$ showed irregular conductance change of the lipid bilayers. $200 \mathrm{pM}$ of gA that creates ion channels was added to verify existense of bilayer for control experiment. The data was digitally filtered by $300 \mathrm{~Hz}$ Bessel filter. 


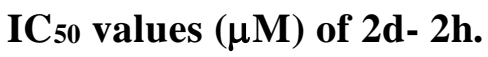

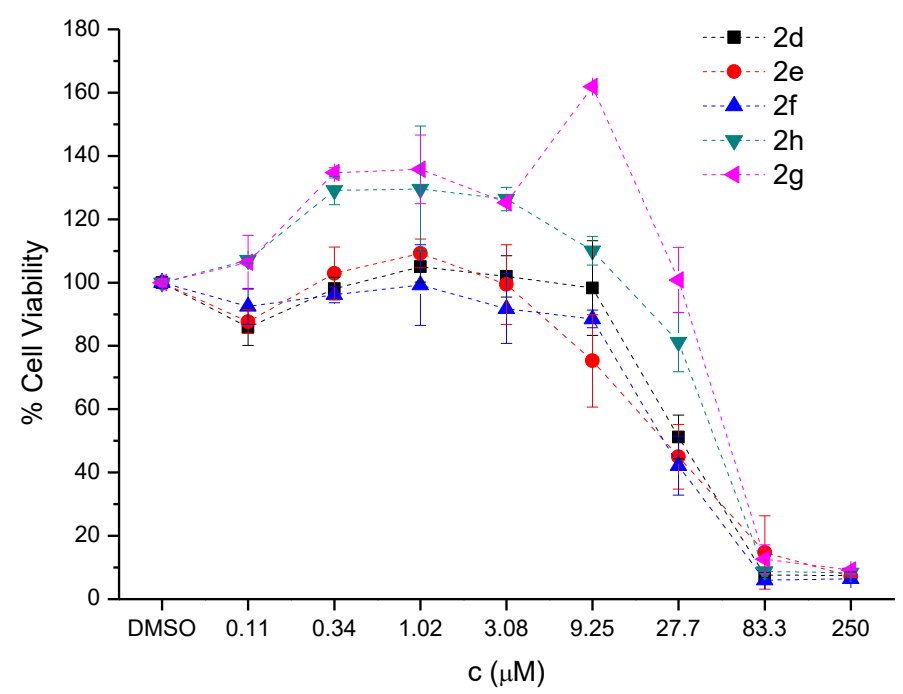

Figure S21. Cell viability obtained from MTT assay upon dose dependent treatment of ion transporters for $48 \mathrm{~h}$ in HT-29 cells.

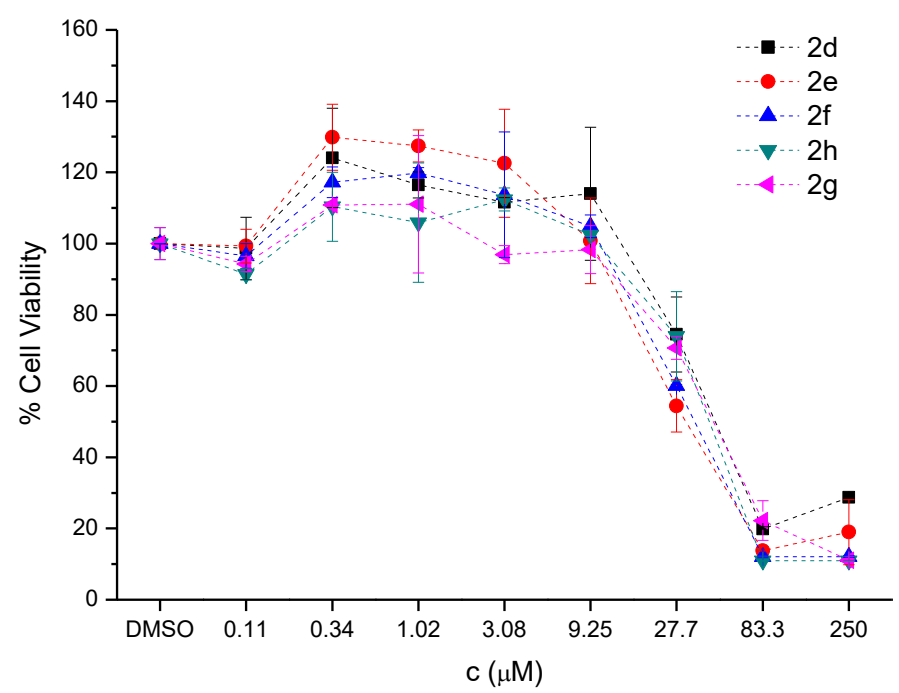

Figure S22. Cell viability obtained from MTT assay upon dose dependent treatment of ion transporters for $48 \mathrm{~h}$ in DLD-1 cells. 


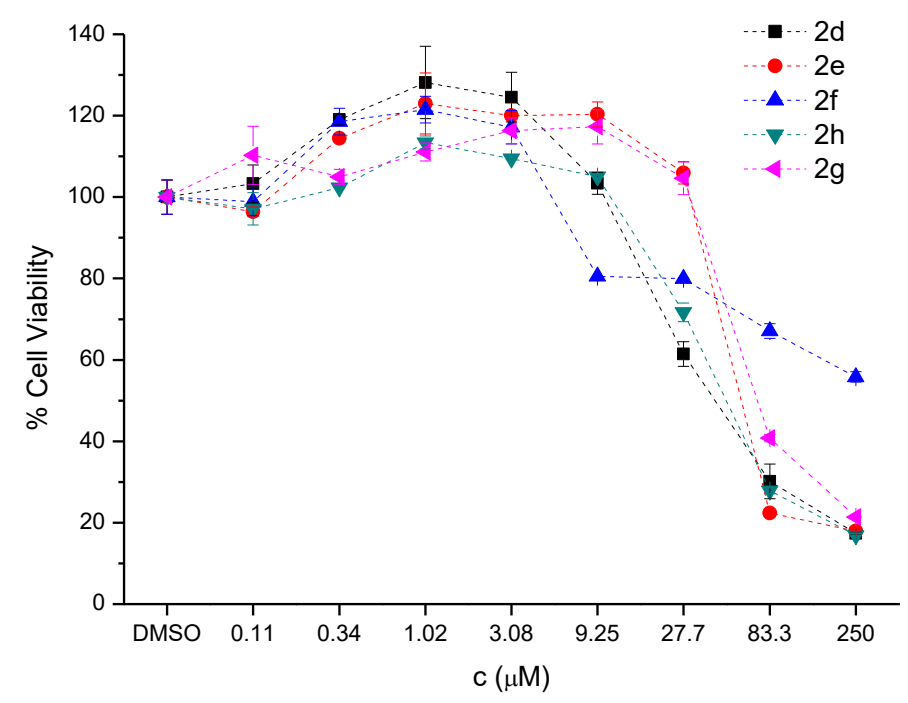

Figure S23. Cell viability obtained from MTT assay upon dose dependent treatment of ion transporters for $48 \mathrm{~h}$ in HCT116 cells.

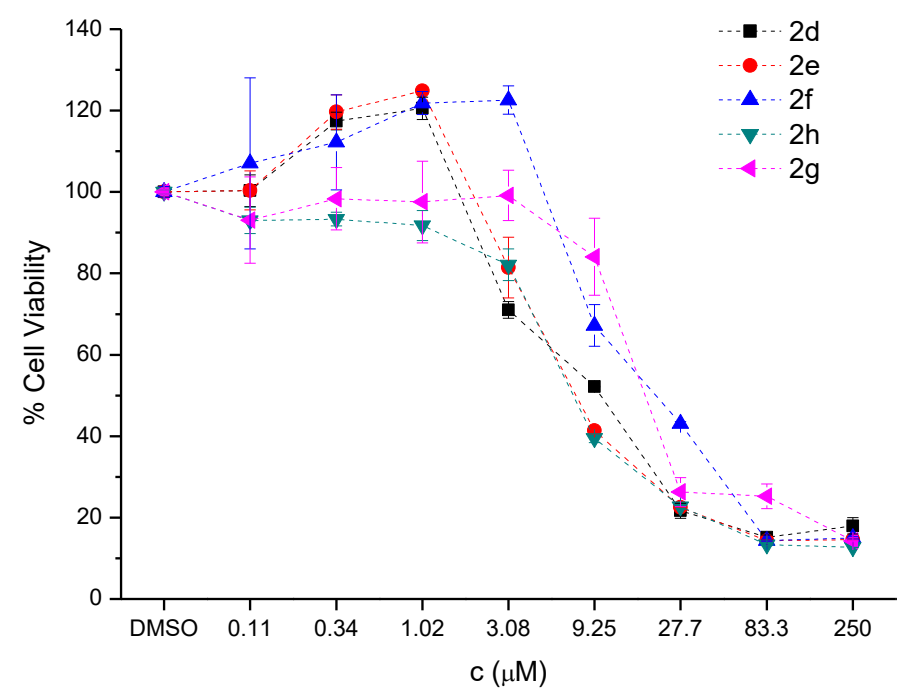

Figure S24. Cell viability obtained from MTT assay upon dose dependent treatment of ion transporters for $48 \mathrm{~h}$ in HeLa cells.. 


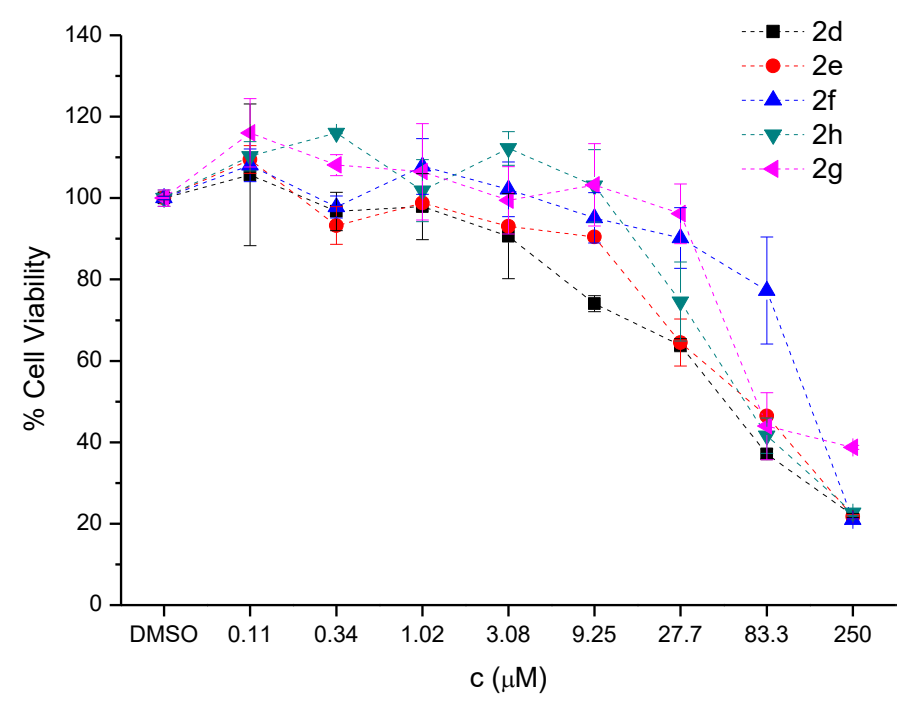

Figure S25. Cell viability obtained from MTT assay upon dose dependent treatment of ion transporters for $48 \mathrm{~h}$ in MIA PaCa-2 cells.

Table S6. IC $_{50}$ values $(\mu \mathrm{M})$ of $\mathbf{2 d -} \mathbf{2 h}$.

\begin{tabular}{cccccc}
\hline & HT29 & DLD -1 & HCT116 & HeLa & MIA PaCa-2 \\
\hline $\mathbf{2 d}$ & 25.8 & 30.0 & 21.1 & 4.7 & 23.35 \\
$\mathbf{2 e}$ & 17.0 & 18.0 & 40.6 & 4.5 & 30.6 \\
$\mathbf{2 f}$ & 22.0 & 23.9 & 68.1 & 11.3 & 99.3 \\
$\mathbf{2 g}$ & 31.0 & 32.1 & 54.5 & 15.9 & 58.2 \\
$\mathbf{2 h}$ & 30.4 & 32.0 & 31.2 & 6.19 & 37.3 \\
\hline
\end{tabular}




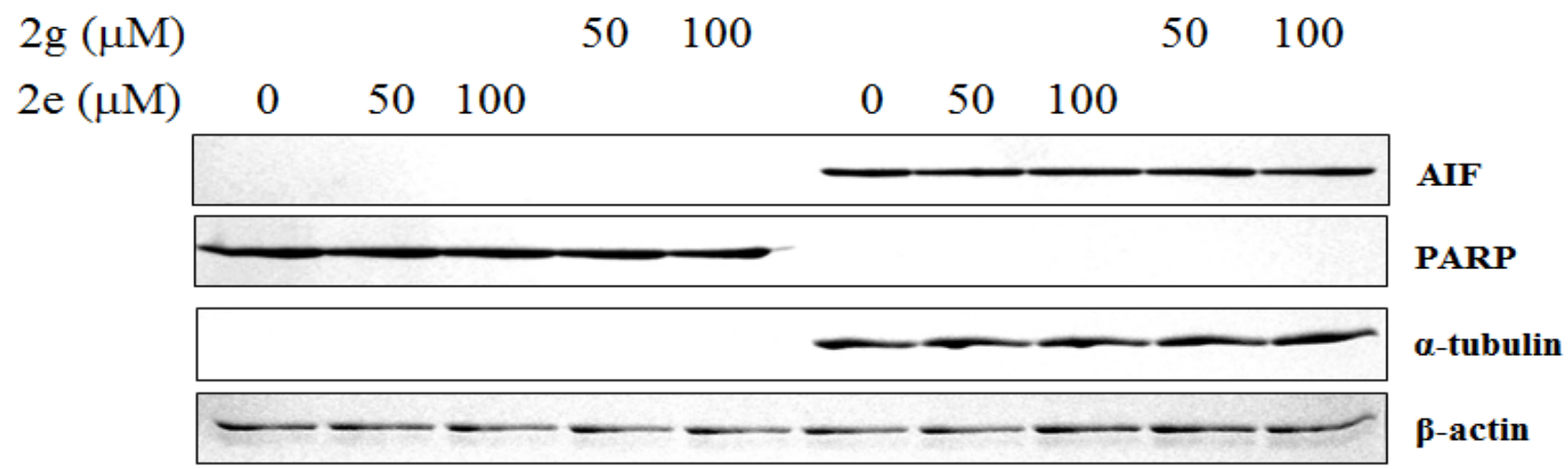

Figure S26. Western analysis reveals that the treatment of $\mathbf{2 e}$ and $\mathbf{2 g}$ do not induce translocation of AIF in Mia PaCa-2 cells.
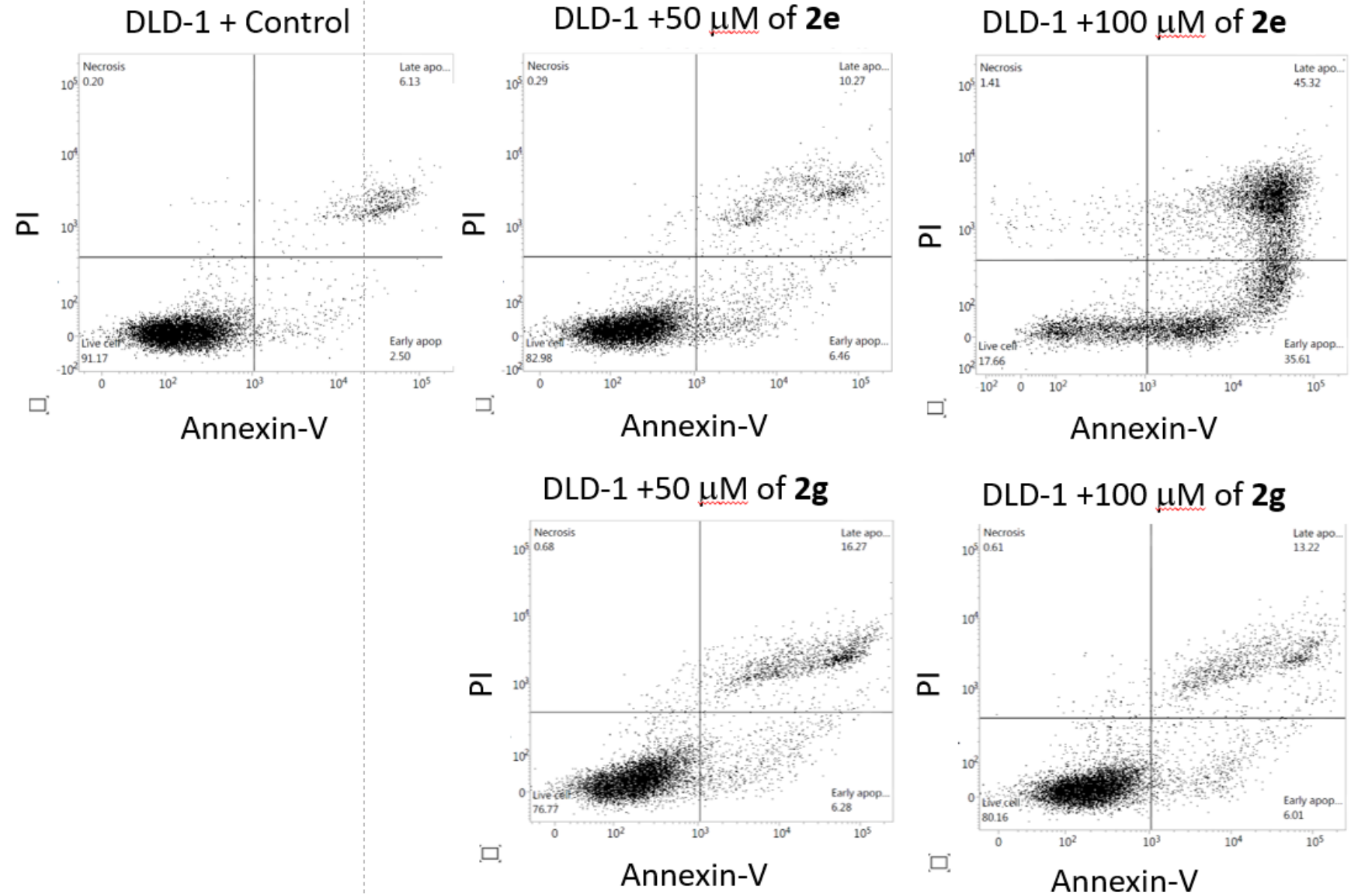

Figure S27. Flow cytometry analysis shows that $100 \mu \mathrm{M}$ of $\mathbf{2 e}$ and $\mathbf{2 g}$ treatment increases ratio of apoptotic or dead cells. $100 \mu \mathrm{M}$ of $2 \mathrm{e}$ treatment increase $80.9 \%$ of apoptotic and dead cells in DLD-1 cells. $100 \mu \mathrm{M}$ of $\mathbf{2 g}$ treatment shows $19.23 \%$ of apoptotic and dead cells. 


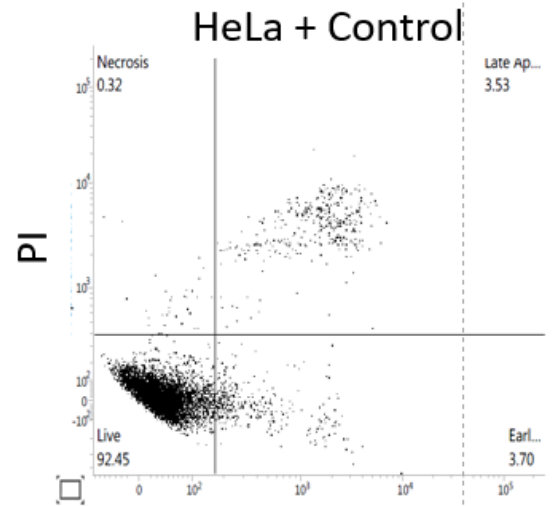

Annexin-V

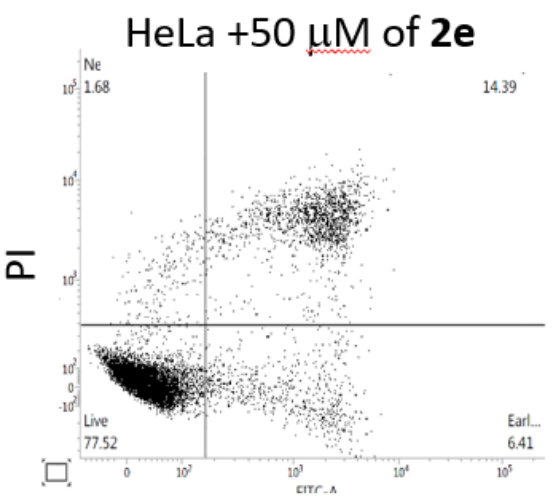

Annexin-V

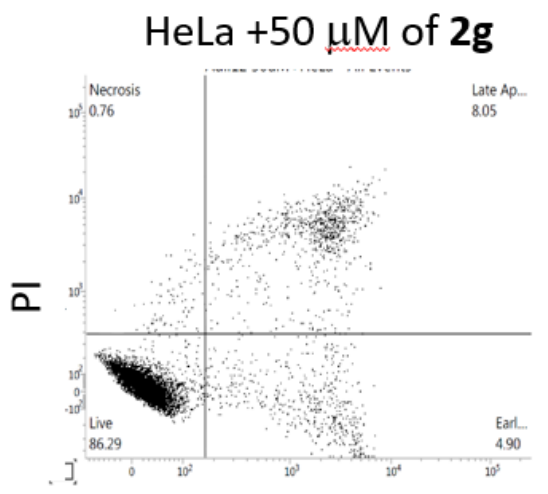

Annexin-V

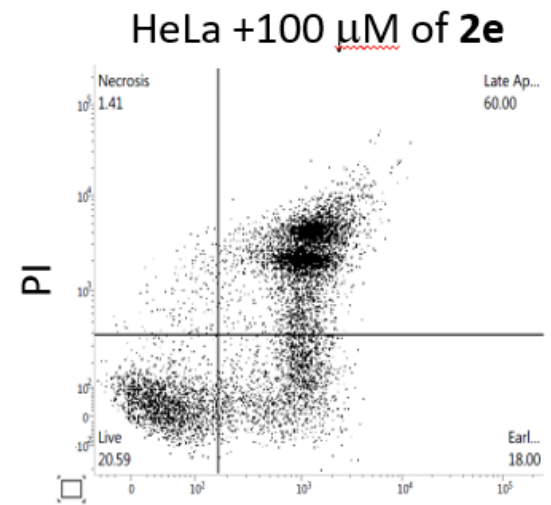

Annexin-V

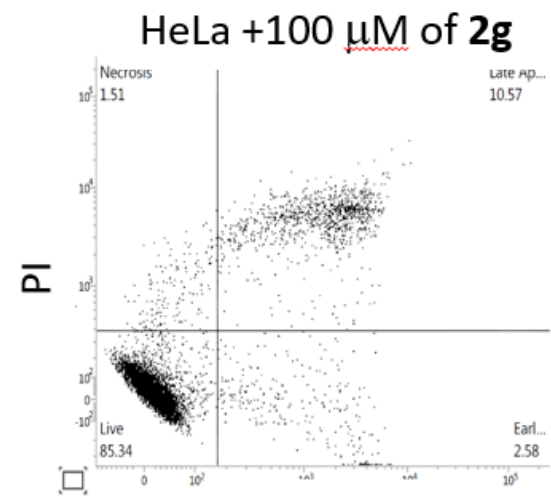

Annexin-V

Figure S28. Flow cytometry analysis shows that $100 \mu \mathrm{M}$ of $\mathbf{2 e}$ and $\mathbf{2 g}$ treatment increase ratio of apoptotic or dead cells. $100 \mu \mathrm{M}$ of $2 \mathrm{e}$ treatment increase $78.0 \%$ of apoptotic and dead cells in HeLa cells. $100 \mu \mathrm{M}$ of $\mathbf{2 g}$ treatment shows $13.15 \%$ of apoptotic and dead cells. 

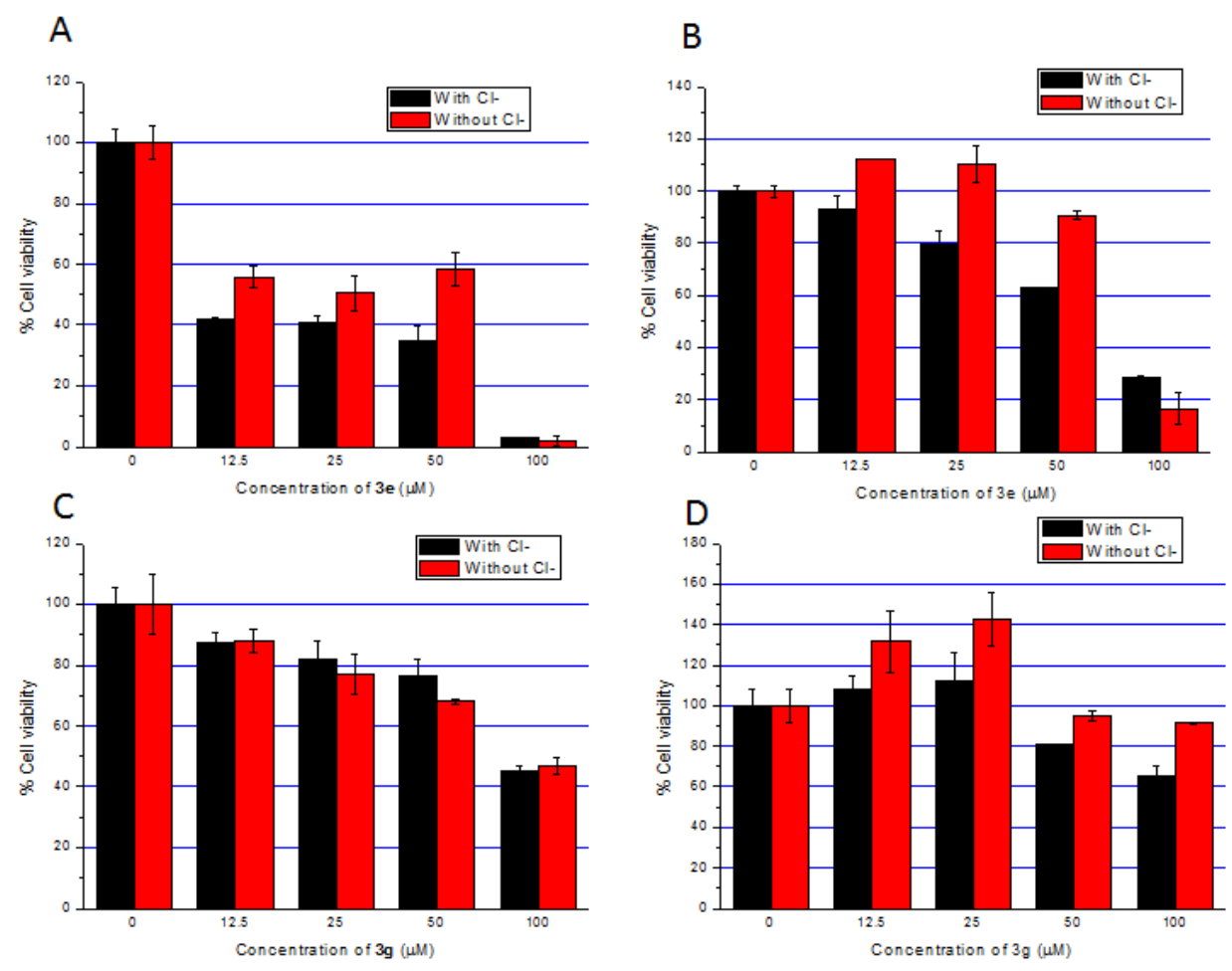

Figure S29. A comparison of the (A) HT29 and (B) DLD-1 cell viability in $\mathrm{Cl}^{-}$-containing and $\mathrm{Cl}^{-}$-free HBSS buffer upon dose dependent treatment of $\mathbf{2 e}$ after $17 \mathrm{~h}$. Similar studies were done for (C) $\mathbf{2 g}$ in HT29 and (D) $2 \mathrm{~g}$ in DLD-1 after $17 \mathrm{~h}$.
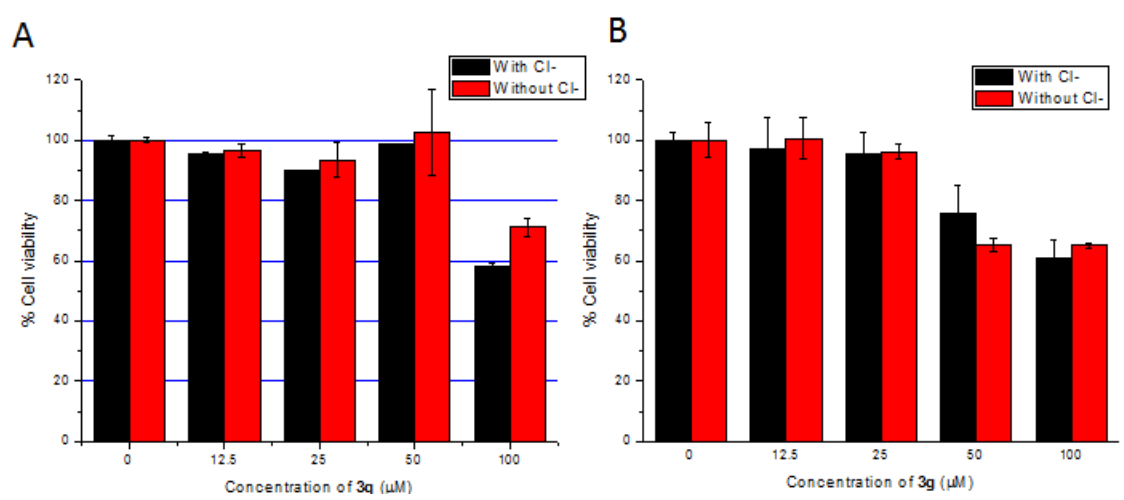

Figure S30. A comparison of the (A) HT29 and (B) DLD-1 cell viability in $\mathrm{Cl}^{-}$-containing and $\mathrm{Cl}^{-}$-free HBSS buffer upon the dose dependent treatment of $2 \mathrm{~g}$ after $6 \mathrm{~h}$. 


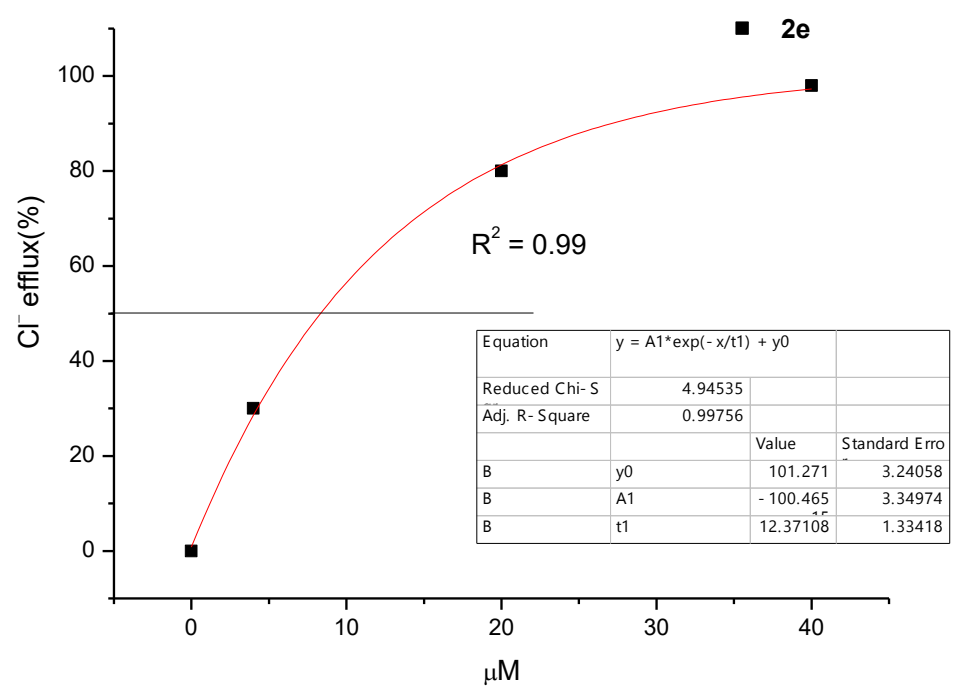

Figure S31. EC 50 value of $\mathbf{2 g}(8.3 \mu \mathrm{M})$ obtained from the above curve fitted to an exponential equation. 


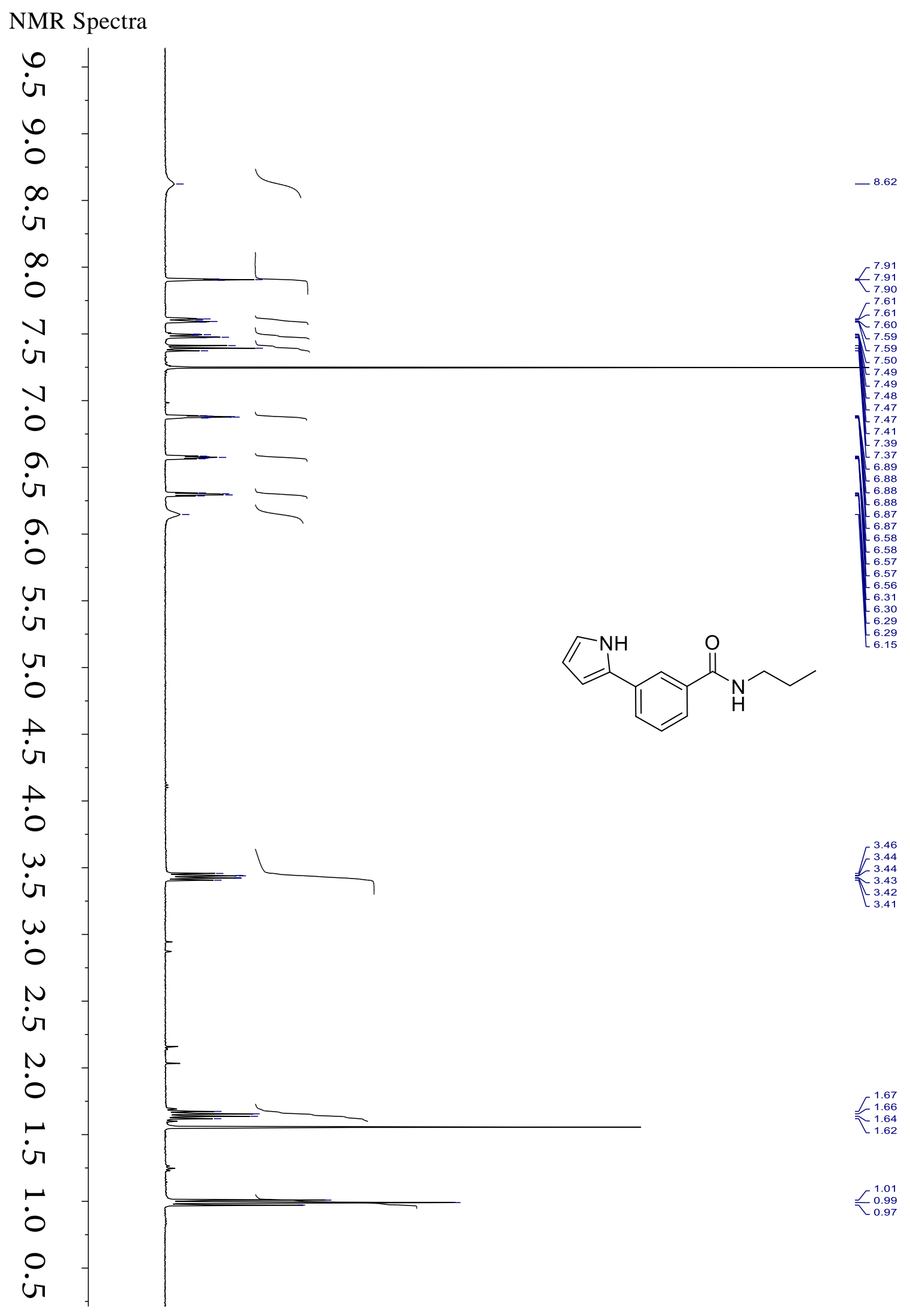

Figure S32. ${ }^{1} \mathrm{H}$ NMR spectrum of $2 \mathbf{a}$ recorded in $\mathrm{CDCl}_{3}$ at $25^{\circ} \mathrm{C}(400 \mathrm{MHz})$ 


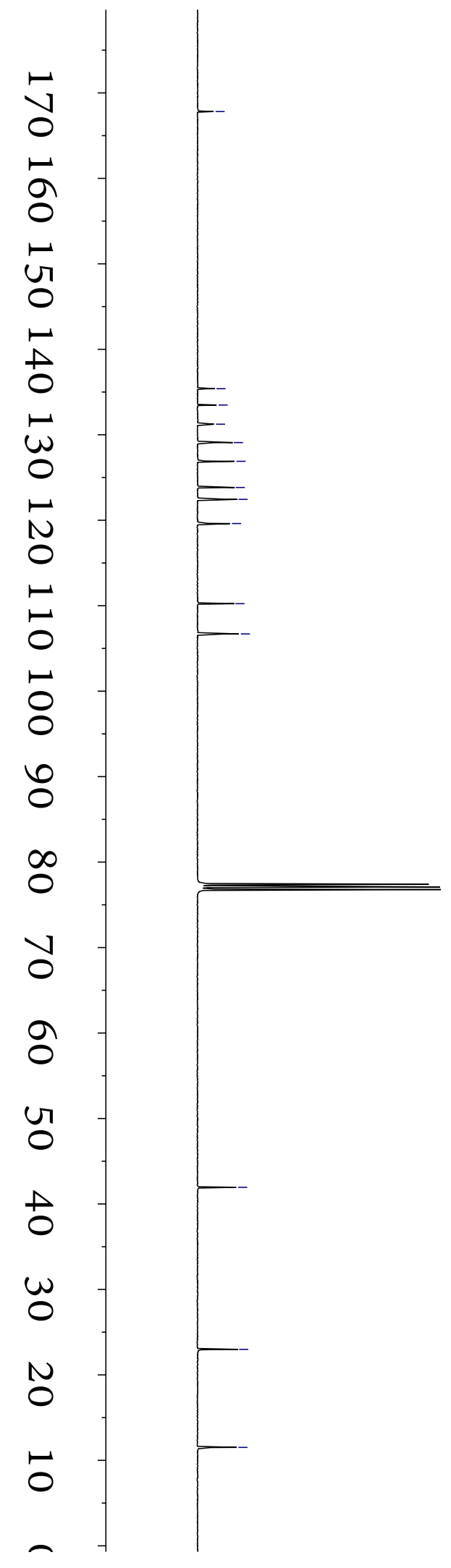

\135.39

133.48

$\begin{array}{r}131.24 \\ -129.09 \\ \hline\end{array}$

$-126.90$

123.83

122.44
119.61

$-110.24$

$-106.70$<smiles>CCCNC(=O)c1cccc(-c2ccc[nH]2)c1</smiles>

Figure S33. ${ }^{13} \mathrm{C}$ NMR spectrum of $\mathbf{2 a}$ recorded in $\mathrm{CDCl}_{3}$ at $25^{\circ} \mathrm{C}(400 \mathrm{MHz})$ 


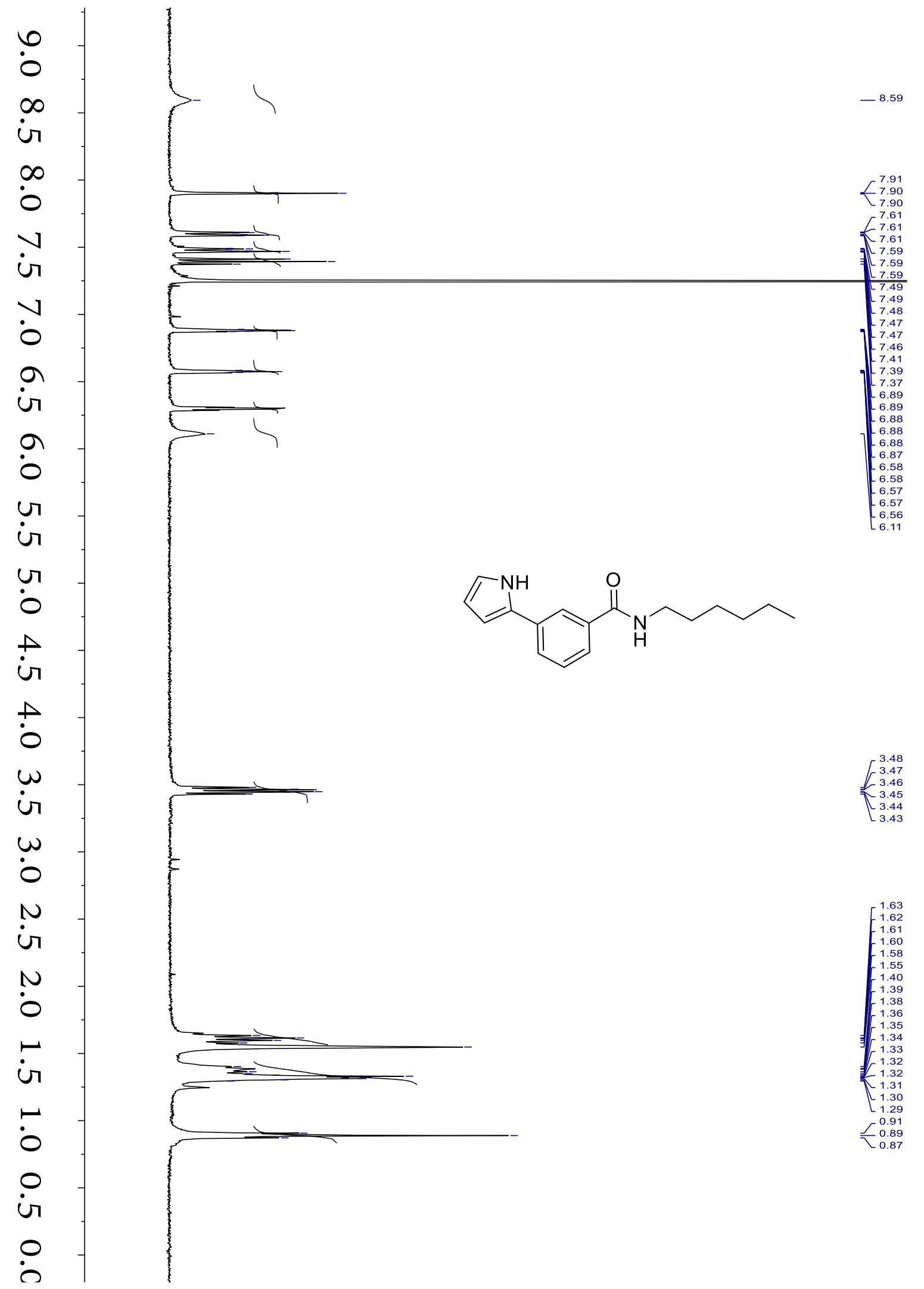

Figure S34. ${ }^{1} \mathrm{H}$ NMR spectrum of $\mathbf{2 b}$ recorded in $\mathrm{CDCl}_{3}$ at $25^{\circ} \mathrm{C}(400 \mathrm{MHz})$ 


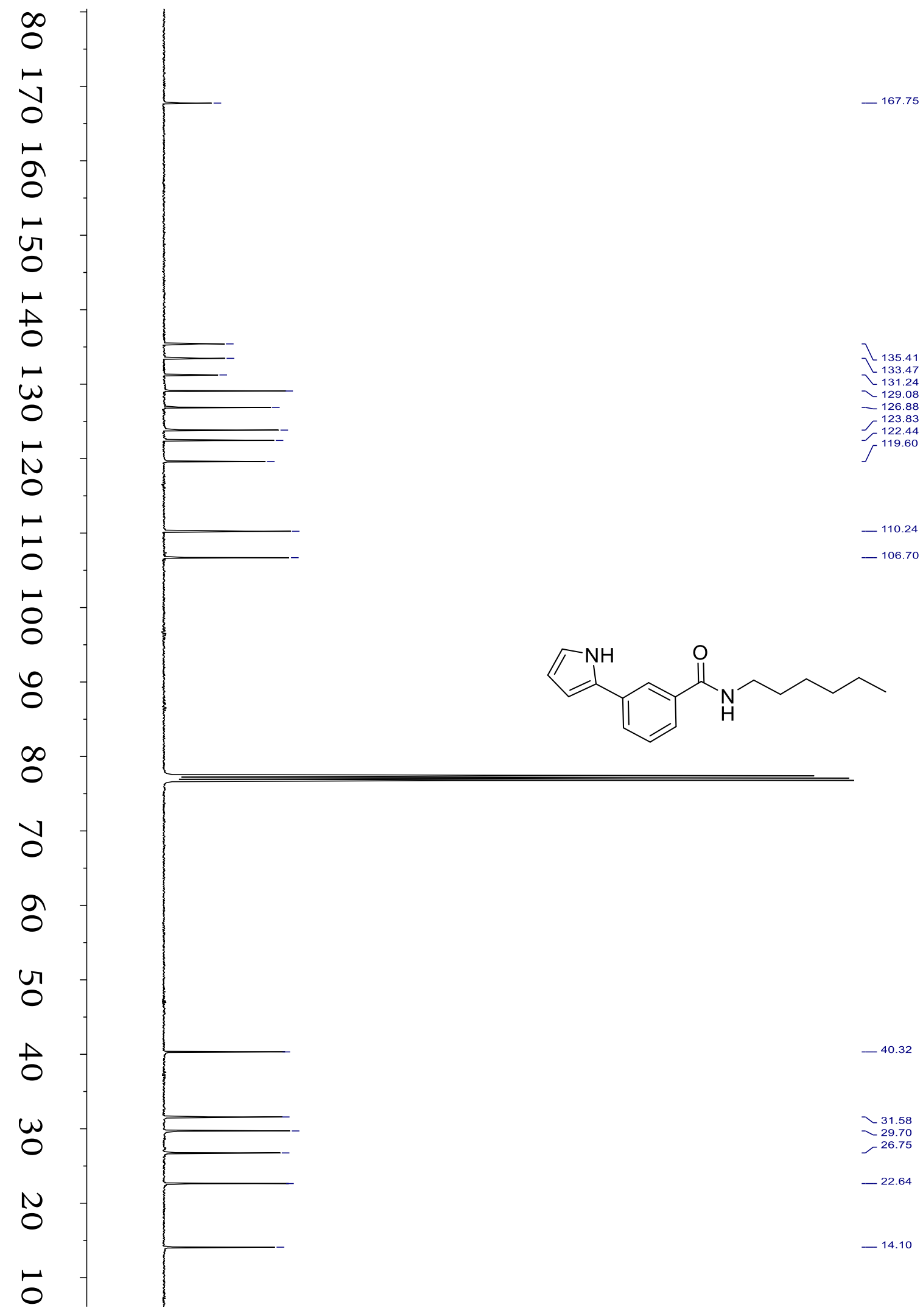

Figure S35. ${ }^{13} \mathrm{C}$ NMR spectrum of $\mathbf{2 b}$ recorded in $\mathrm{CDCl}_{3}$ at $25^{\circ} \mathrm{C}(400 \mathrm{MHz})$ 


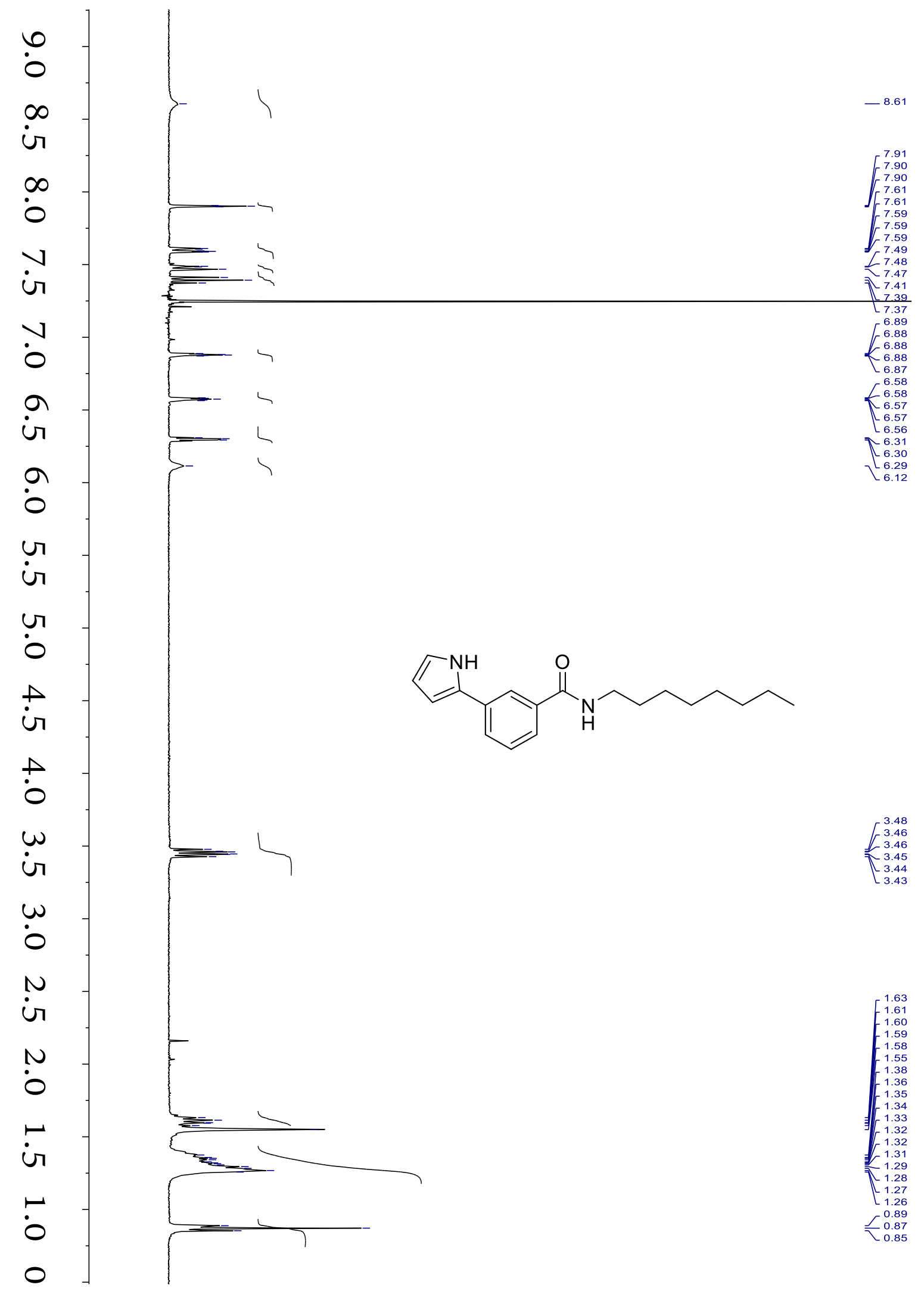

Figure S36. ${ }^{1} \mathrm{H}$ NMR spectrum of $2 \mathrm{c}$ recorded in $\mathrm{CDCl}_{3}$ at $25^{\circ} \mathrm{C}(400 \mathrm{MHz})$ 


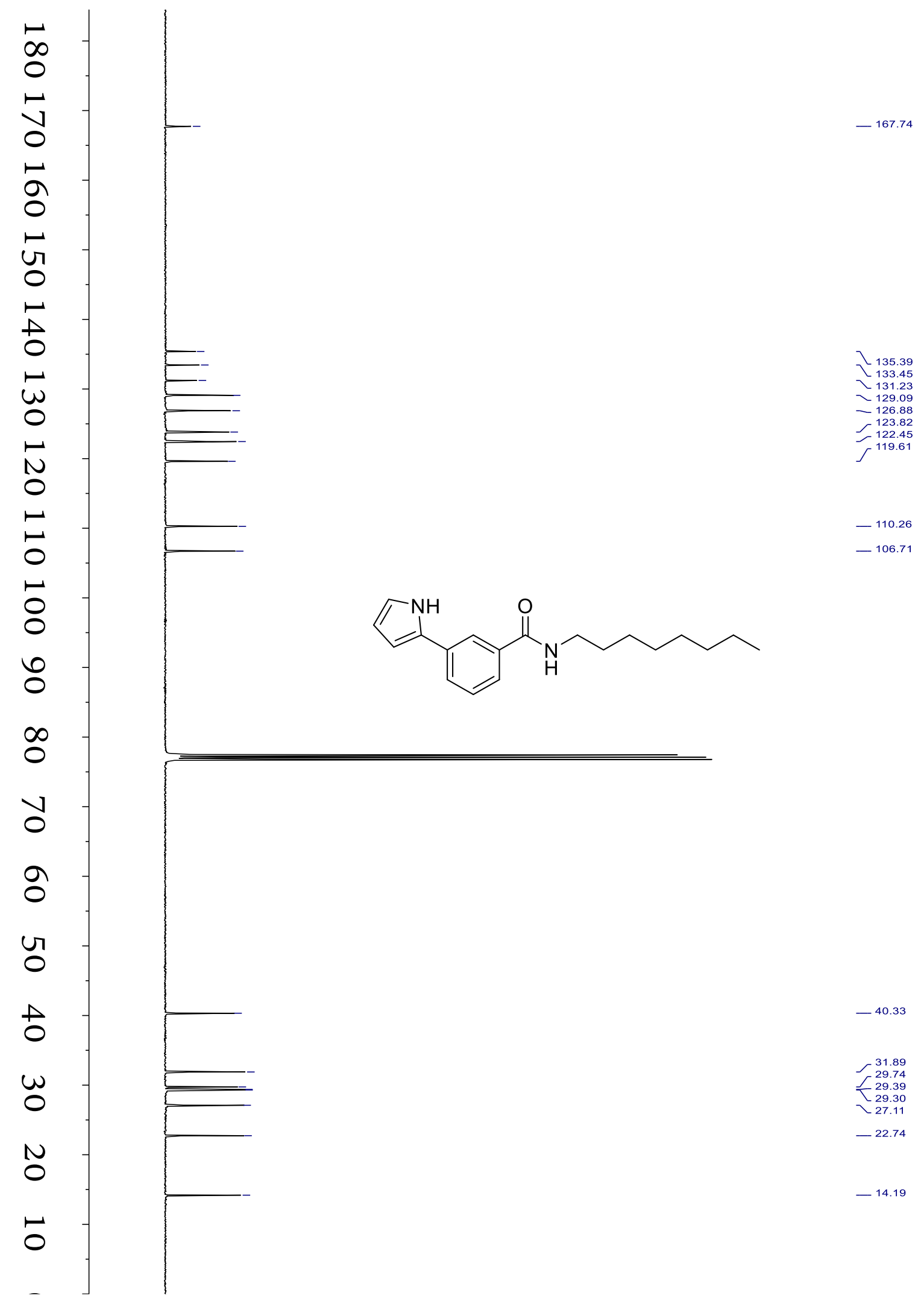

Figure S37. ${ }^{13} \mathrm{C}$ NMR spectrum of $2 \mathrm{c}$ recorded in $\mathrm{CDCl}_{3}$ at $25^{\circ} \mathrm{C}(400 \mathrm{MHz})$ 


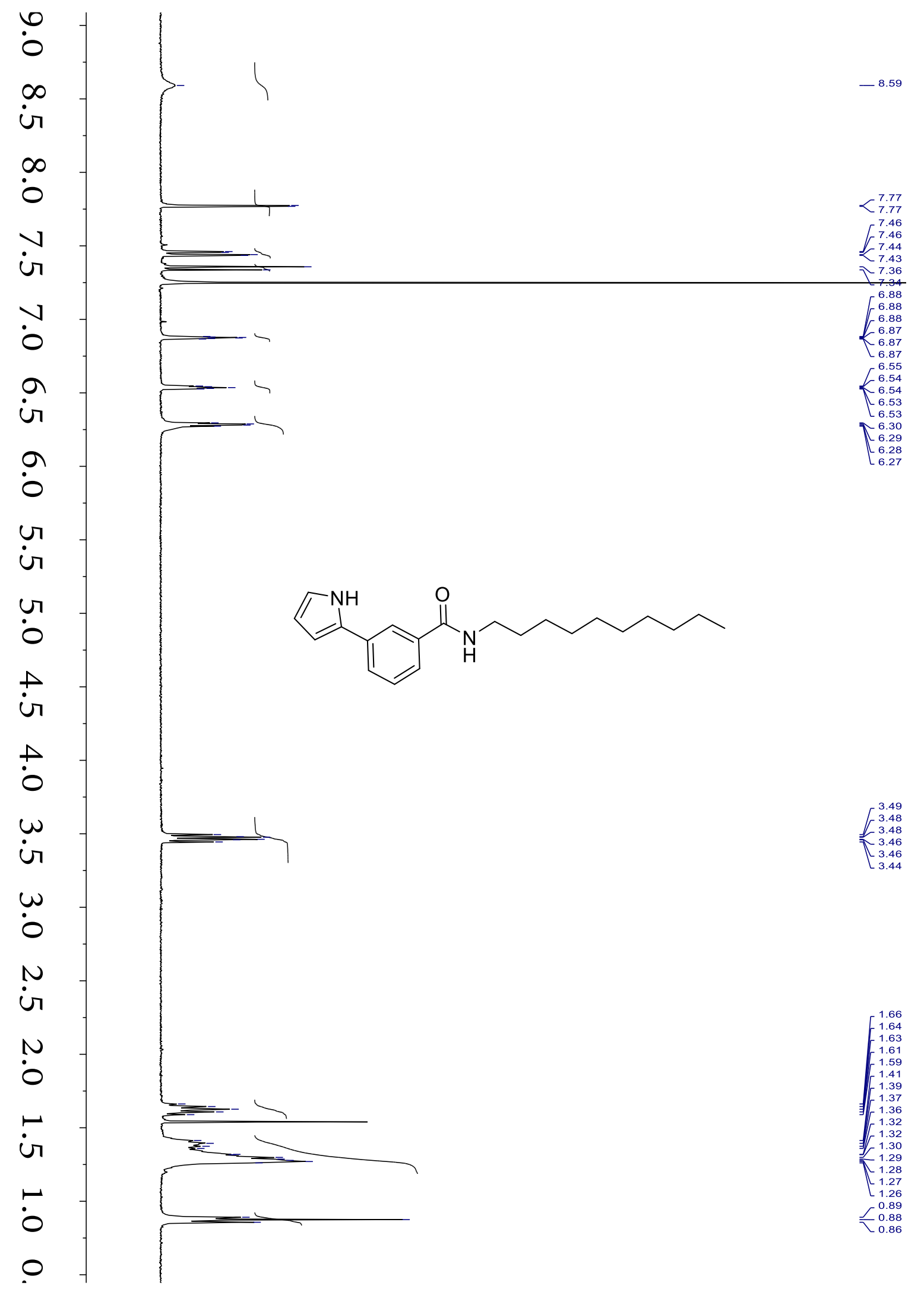

Figure S38. ${ }^{1} \mathrm{H}$ NMR spectrum of $\mathbf{2 d}$ recorded in $\mathrm{CDCl}_{3}$ at $25^{\circ} \mathrm{C}(400 \mathrm{MHz})$ 


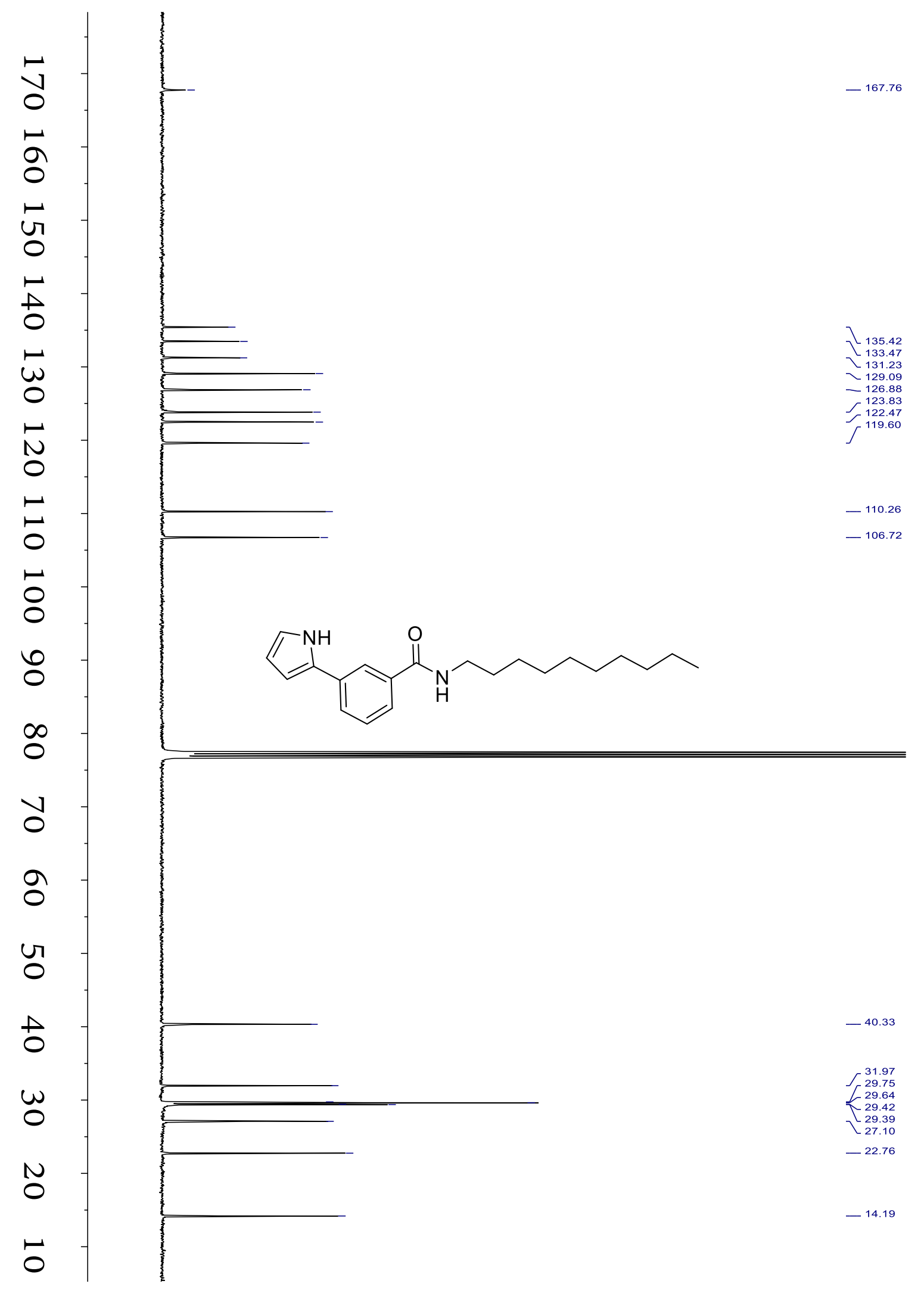

Figure S39. ${ }^{13} \mathrm{C}$ NMR spectrum of $\mathbf{2 d}$ recorded in $\mathrm{CDCl}_{3}$ at $25^{\circ} \mathrm{C}(400 \mathrm{MHz})$ 


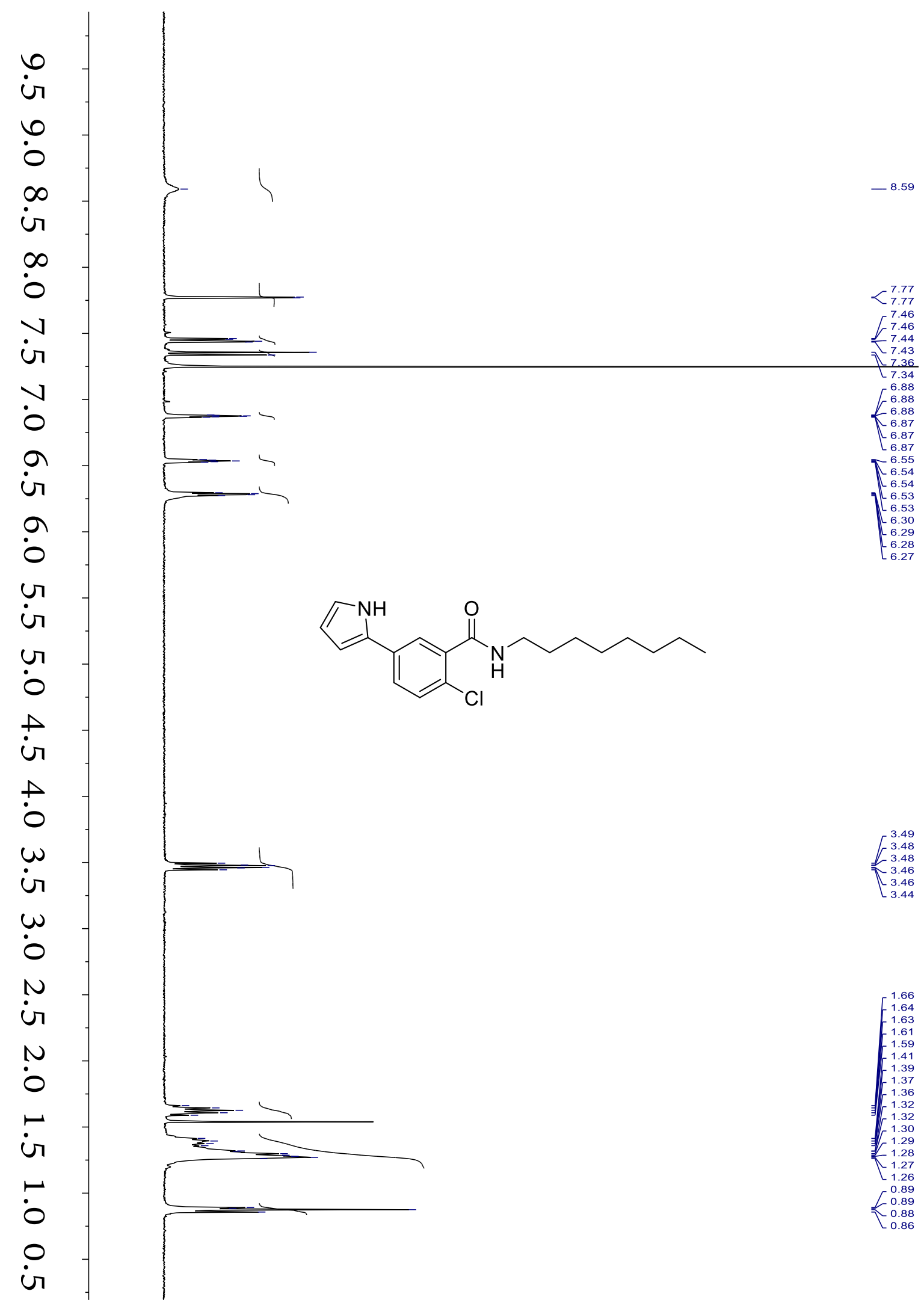

Figure S40. ${ }^{1} \mathrm{H}$ NMR spectrum of $2 \mathbf{e}$ recorded in $\mathrm{CDCl}_{3}$ at $25^{\circ} \mathrm{C}(400 \mathrm{MHz})$ 


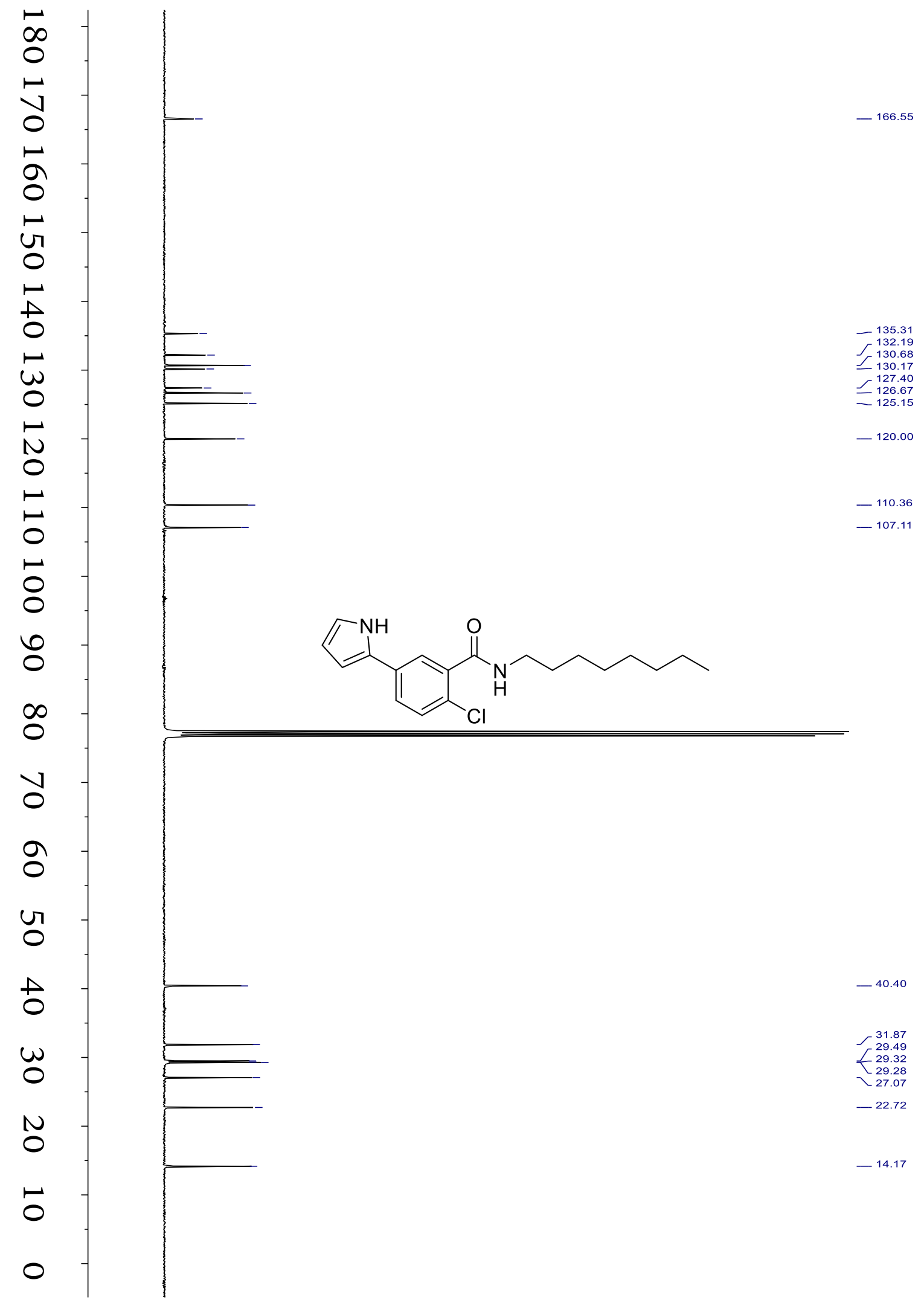

Figure S41. ${ }^{13} \mathrm{C}$ NMR spectrum of $2 \mathrm{e}$ recorded in $\mathrm{CDCl}_{3}$ at $25^{\circ} \mathrm{C}(400 \mathrm{MHz})$ 


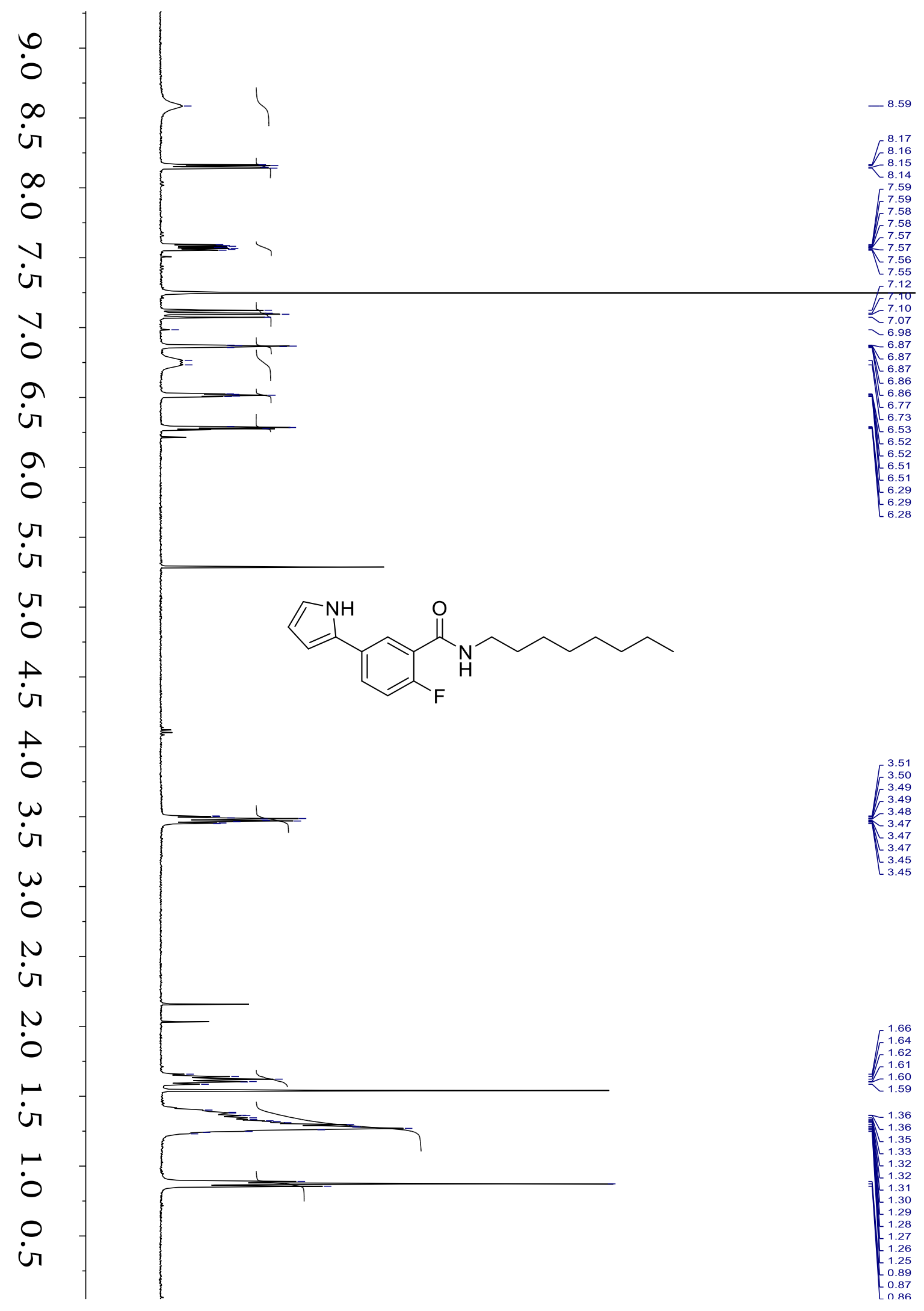

Figure S42. ${ }^{1} \mathrm{H}$ NMR spectrum of $\mathbf{2 f}$ recorded in $\mathrm{CDCl}_{3}$ at $25^{\circ} \mathrm{C}(400 \mathrm{MHz})$ 


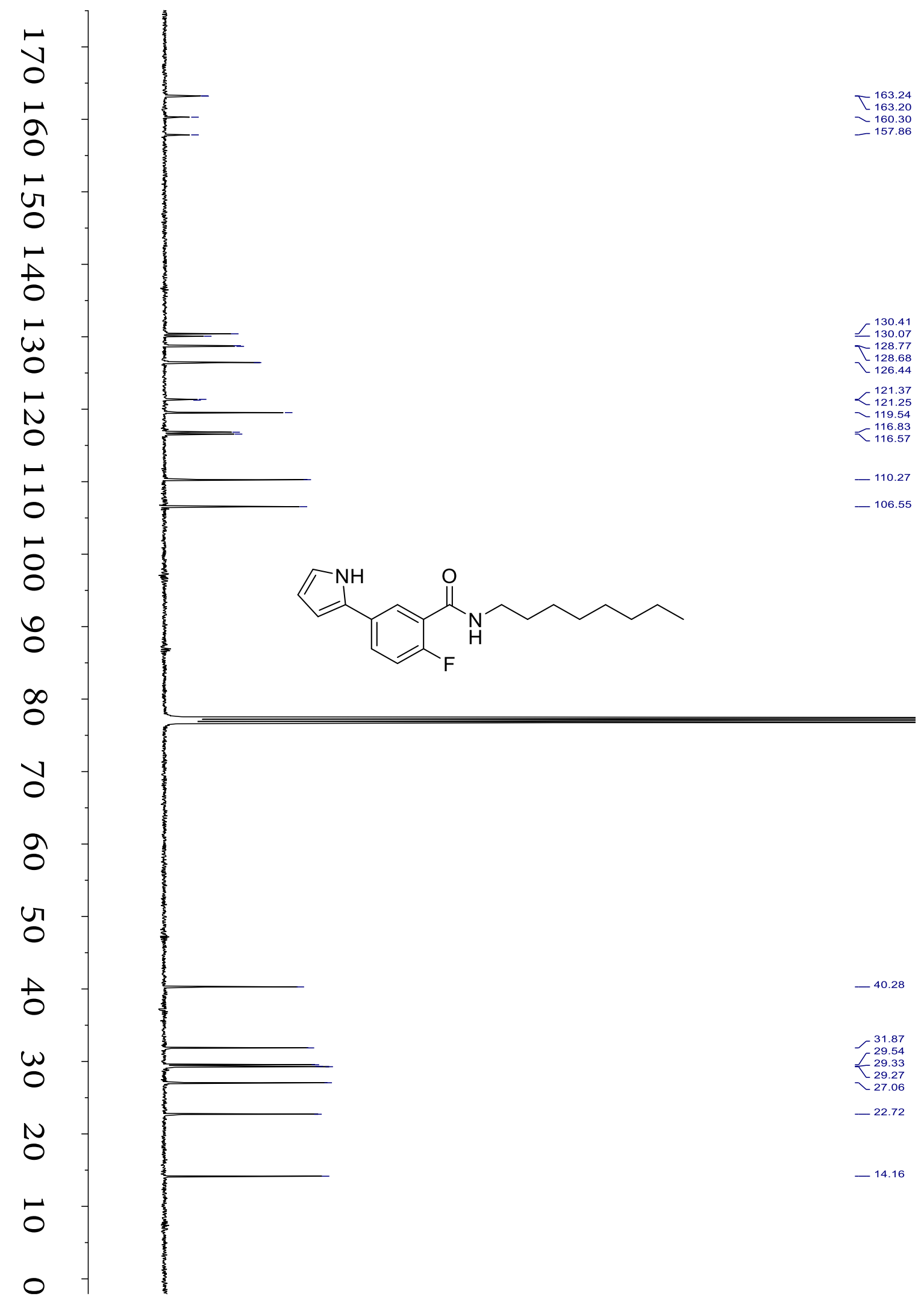

Figure S43. ${ }^{13} \mathrm{C}$ NMR spectrum of $2 \mathbf{f}$ recorded in $\mathrm{CDCl}_{3}$ at $25^{\circ} \mathrm{C}(400 \mathrm{MHz})$ 


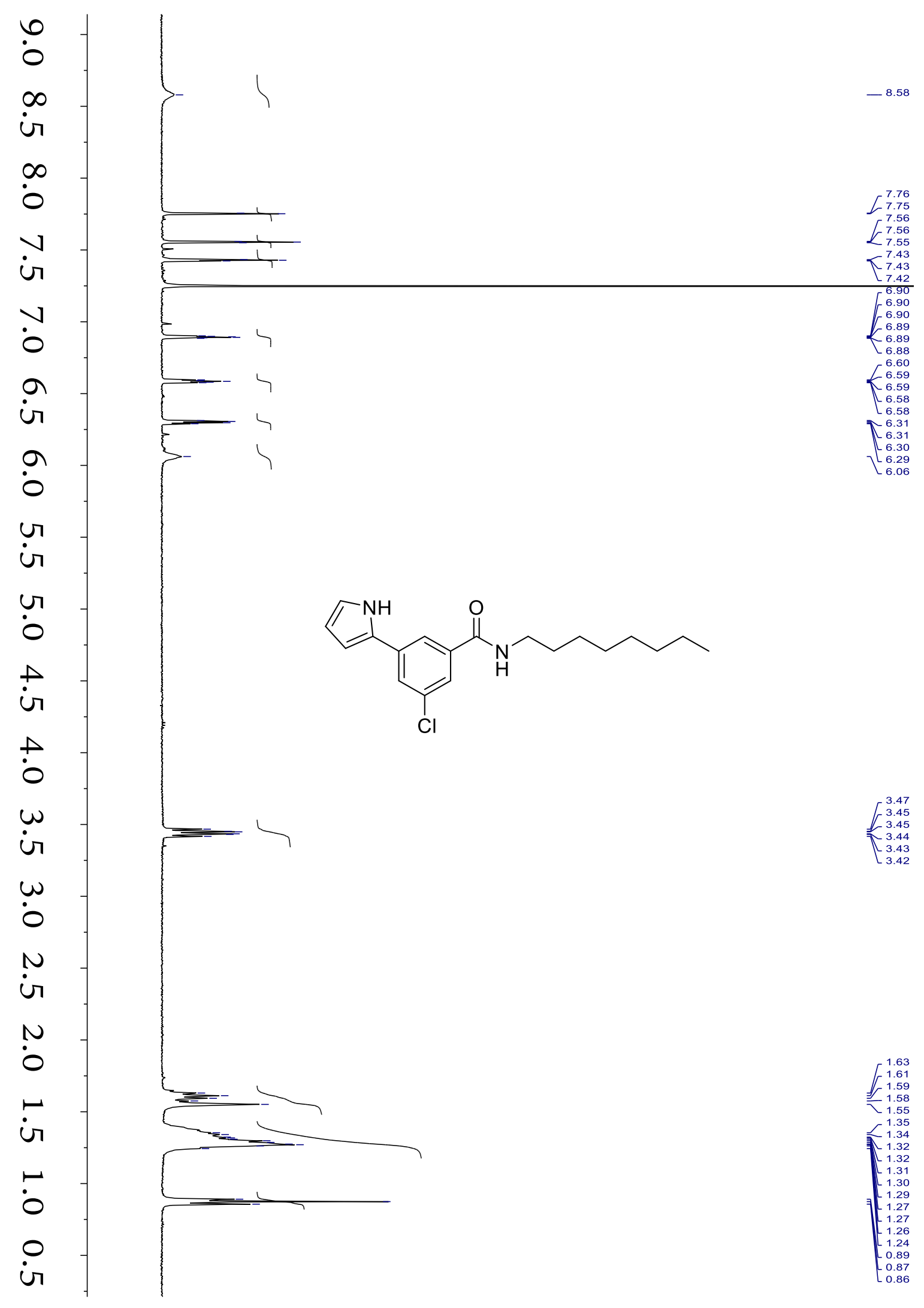

Figure S44. ${ }^{1} \mathrm{H}$ NMR spectrum of $2 \mathrm{~g}$ recorded in $\mathrm{CDCl}_{3}$ at $25^{\circ} \mathrm{C}(400 \mathrm{MHz})$ 


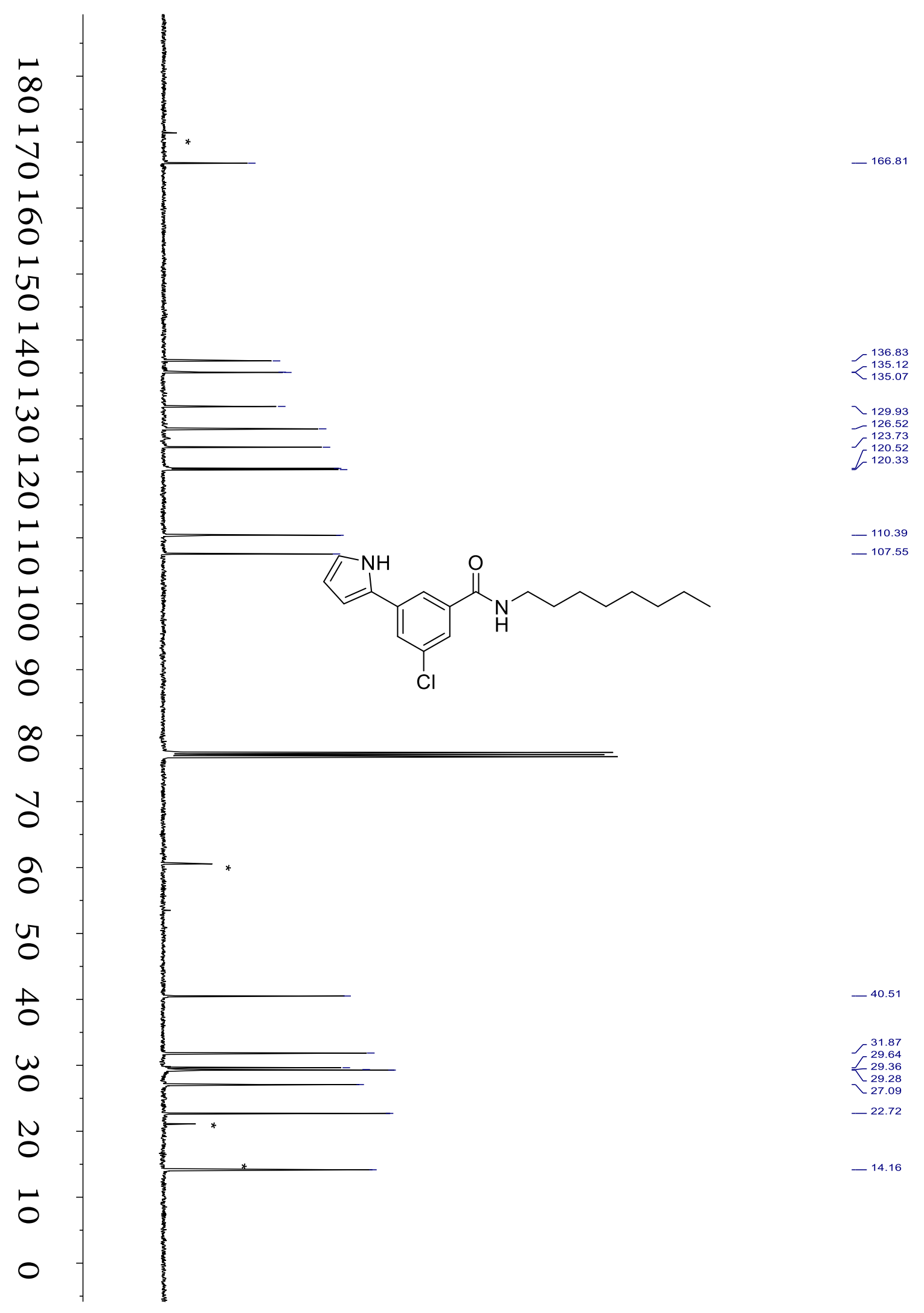

Figure $\mathbf{S 4 5} .{ }^{13} \mathrm{C}$ NMR spectrum of $2 \mathrm{~g}$ recorded in $\mathrm{CDCl}_{3}\left({ }^{*}\right.$ residue of EtOAc) at $25^{\circ} \mathrm{C}(400 \mathrm{MHz})$ 


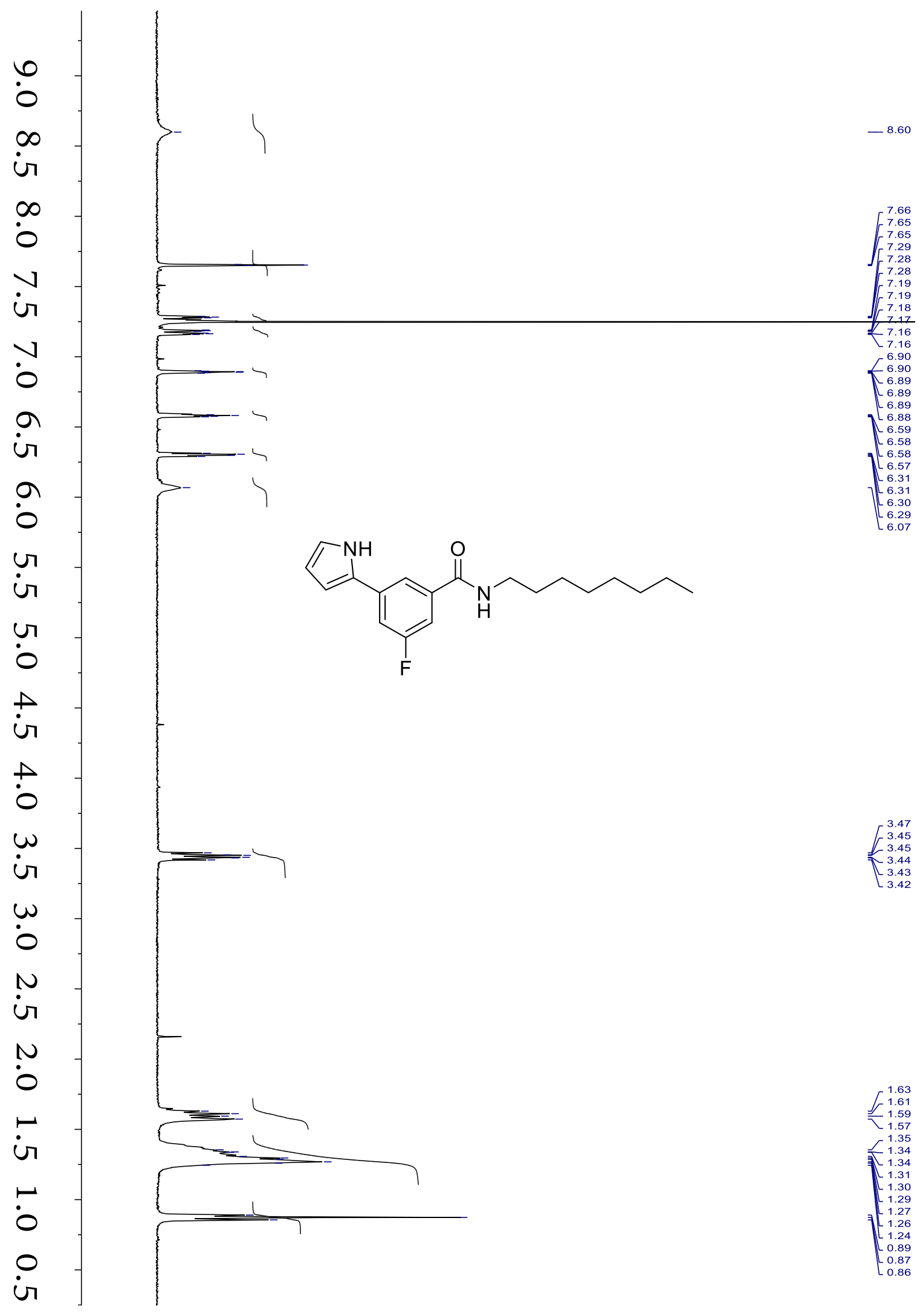

Figure S46. ${ }^{1} \mathrm{H}$ NMR spectrum of $\mathbf{2 h}$ recorded in $\mathrm{CDCl}_{3}$ at $25^{\circ} \mathrm{C}(400 \mathrm{MHz})$ 


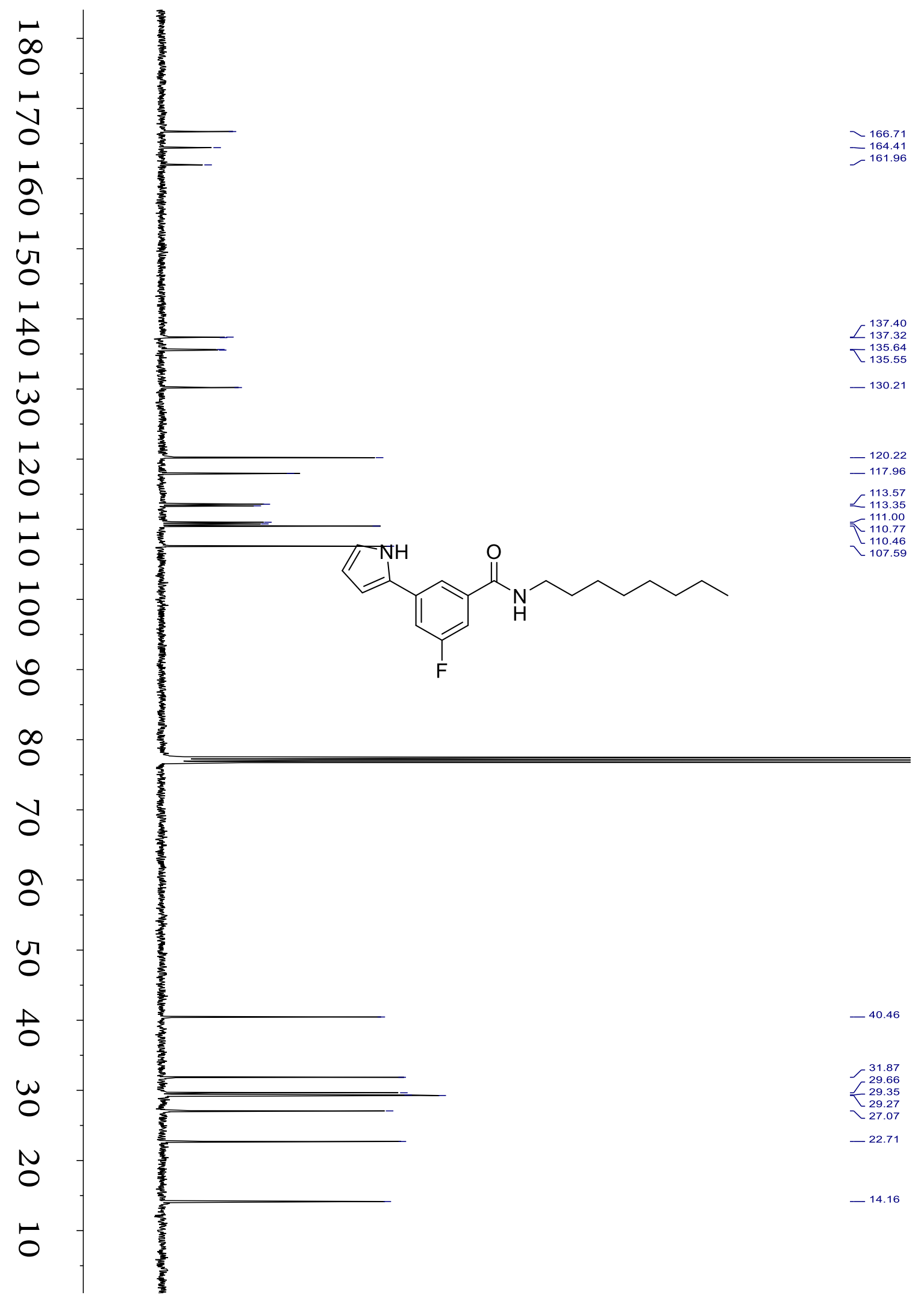

Figure S47. ${ }^{13} \mathrm{C}$ NMR spectrum of $2 \mathbf{h}$ recorded in $\mathrm{CDCl}_{3}$ at $25^{\circ} \mathrm{C}(400 \mathrm{MHz})$ 